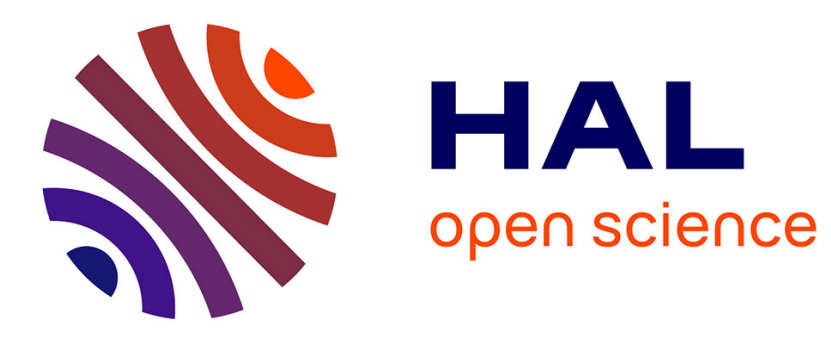

\title{
Triassic--Jurassic evolution of the eastern North China Craton: Insights from the Lushun-Dalian area, South Liaodong Peninsula, NE China
}

Zhiheng Ren, Wei Lin, Michel Faure, Lingtong Meng, Huabiao Qiu, Jipei Zeng

\section{- To cite this version:}

Zhiheng Ren, Wei Lin, Michel Faure, Lingtong Meng, Huabiao Qiu, et al.. Triassic-Jurassic evolution of the eastern North China Craton: Insights from the Lushun-Dalian area, South Liaodong Peninsula, NE China. Geological Society of America Bulletin, 2020, 133 (1-2), pp.393-408. 10.1130/B35533.1 . insu-02891784

\section{HAL Id: insu-02891784 \\ https://hal-insu.archives-ouvertes.fr/insu-02891784}

Submitted on 7 Aug 2020

HAL is a multi-disciplinary open access archive for the deposit and dissemination of scientific research documents, whether they are published or not. The documents may come from teaching and research institutions in France or abroad, or from public or private research centers.
L'archive ouverte pluridisciplinaire HAL, est destinée au dépôt et à la diffusion de documents scientifiques de niveau recherche, publiés ou non, émanant des établissements d'enseignement et de recherche français ou étrangers, des laboratoires publics ou privés. 
Triassic-Jurassic evolution of the eastern North China Craton: insights from the Lushun-Dalian area, South Liaodong Peninsula, NE China

4

Zhiheng Ren ${ }^{1,2}$, Wei Lin ${ }^{1,2 *}$, Michel Faure ${ }^{3}$, Lingtong Meng ${ }^{1,2}$, Huabiao Qiu ${ }^{1,2,3}$, Jipei Zeng ${ }^{1,2}$

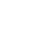

${ }^{1}$ State Key Laboratory of Lithospheric Evolution, Institute of Geology and Geophysics, Innovation Academy for Earth Science, Chinese Academy of Sciences, Beijing 100029,

\section{China}

${ }^{2}$ College of Earth and Planetary Sciences, University of Chinese Academy of Sciences, Beijing 100049, China

${ }^{3}$ Institut des Sciences de la Terre d'Orléans, Université d'Orléans, UMR 7327, $1 \mathrm{~A}$ Rue de la Férollerie, 45071 Orléans Cedex 2, France

\section{Abstract}

The Lushun-Dalian area of the South Liaodong Peninsula located in the SE margin of the North China Craton (NCC) exposes a suite of Middle-Late Proterozoic low-grade metamorphic sedimentary rocks which can be divided into a lower competent layer, a middle incompetent layer, and an upper competent layer on the basis of lithology and deformation style. Two stages of deformation recorded both in the metasedimentary rocks and a magmatic complex intruded in them indicate that the Lushun-Dalian area is a key region to decipher the Triassic-Jurassic tectonic evolution of the eastern NCC. The earliest $\mathrm{D}_{1}$ deformation mylonitized the magmatic complex and thrusted it NE- 
ward over the low-grade metasedimentary rocks, in which a series of NE-verging folds and NE-directed brittle thrust faults developed. The $\mathrm{D}_{2}$ deformation erased the $\mathrm{D}_{1}$ fabrics in the incompetent layer by a top-to-the-NW ductile shearing and refolded the $\mathrm{D}_{1}$ fabrics in the lower and upper competent units, producing a series of km-scale SWplunging folds. New SIMS zircon U-Pb ages from the magmatic complex combined with the unconformity between the low-grade metasedimentary rocks and the Early Cretaceous volcanic rocks indicate that $\mathrm{D}_{1}$ and $\mathrm{D}_{2}$ occurred after $211 \mathrm{Ma}$ and before the Early Cretaceous. The decrease of the deformation intensity of $\mathrm{D}_{1}$ and $\mathrm{D}_{2}$ from the Lushun-Dalian area toward the interior of the NCC in the NE and NW directions suggests that $\mathrm{D}_{1}$ was the structural response in the overriding plate to the NCC-South China Block (SCB) convergence during the Late Triassic to Early Jurassic, and $\mathrm{D}_{2}$ was the structural response to the NW-ward subduction of the Paleo-Pacific plate beneath the NCC in the Middle-Late Jurassic. The superimposition of $\mathrm{D}_{2}$ on $\mathrm{D}_{1}$ recorded a significant tectonic transformation from the nearly E-W trending Tethysian domain to the NE-SW trending Pacific domain.

Keywords: Superimposed compressional deformation; Mesozoic tectonics of East Asia; Paleo-Pacific Subduction; South Liaodong Peninsula; North China Craton-South China Block convergence

\section{Introduction}

During the long orogenesis of continent-continent collision, the bulk of 
compressional strain is mostly accumulated in the subducting plate (Schäfer et al., 2000), and lead to the formation of broad external fold-and-thrust belts and the largescale internal HP-UHP metamorphic terranes, such as those in the Western Alps (Chopin, 1984; Escher et al., 1993; Ceriani and Schmid, 2004; Ganne et al., 2005). Contrastingly, the overriding plate absorbed the deformation in smaller, steeper foldand-thrust belts with opposite polarity to the main tectonic transport direction (Schäfer et al., 2000). Such an asymmetry has been corroborated as a fundamental characteristic of the collisional orogens by numerical and analogue models (Willett et al., 1993; Beaumont et al., 1996). The relatively weak deformation and metamorphism may be the reason why less attention had been paid on the compressional deformation in the overriding plate compared to the lower one. However, such structural studies were demonstrated to be helpful in deciphering the convergence history between two continental plates, such as those in the Eastern and Southern Alps (Ratschbacher, 1986; Ratschbacher and Oertel, 1987; Doglioni, 1987; Linzer et al., 1995; Castellarin and Cantelli, 2000).

Comparing to the above Cenozoic collisional orogens, evidence for the compressional deformation in the overriding plate of a pre-Cenozoic collisional orogen, however, is still rare (Schäfer et al., 2000; Higgins and Leslie, 2000). The Dabie-Sulu orogenic belt of the central-eastern China is widely considered to be resulted from the Triassic continental convergence between the NCC and the SCB (Fig. 1; Mattauer et al., 1985; Li et al., 1993; Okay et al., 1993). Extensive fold-and-thrust belts and the world's largest UHP terranes are well exposed in the northern margin of the SCB (Fig. 
1; Faure et al., 1998, 1999, 2001, 2003a, 2003b; Lin et al., 2000, 2001, 2005a, 2005b, 2005c, 2009). During the last 30 years, limited structural analysis has been focused on the deep subduction of continental crust of SCB and the subsequent exhumation of HPUHP terranes (Xue et al., 1996; Wang et al., 1998; Faure et al., 1999, 2003a, 2003b; Wang et al., 2003; Xu et al., 2006; Wang et al., 2010; Liu et al., 2011a; Li et al., 2009a, 2010, 2011). However, the compressional structural response to these processes in the overriding plate (i. e. the southern margin of NCC) that may provide us important insights into the Triassic orogenesis had been rarely studied. This is partly due to the poor exposure of pre-Mesozoic rocks that were covered by the Late Mesozoic Hefei Basin north of the Dabie orogenic belt (Fig. 1; Zhu et al., 2017), or the intense modification by the lithosphere-scale Early Cretaceous extension in the Jiaobei terrane north of the Sulu belt (Charles et al., 2011; 2013; Lin et al., 2015; Xia et al., 2016). By contrast, the Mesozoic compressional structures derived from the NW-SE and the NE-SW shortening were reported in the weakly metamorphosed sedimentary rocks of the Lushun-Dalian area, South Liaodong Peninsula about $100 \mathrm{~km}$ north of the Sulu orogenic belt (Fig. 2a). However, controversies still exist in their timing, superimposition relationship and geodynamic setting (Xu et al., 1991; Yin and Nie, 1993; Wang et al., 2000a, 2000b; Yang et al., 2002, 2011; Lin et al., 2007, 2008). Xu et al. (1991) argued that the NW-directed folds and thrusts are the dominant structures in the sedimentary cover of the Lushun-Dalian area. The timing of the NW-SE compression is loosely constrained from Triassic to Early Jurassic. In their indentation model, Yin and Nie (1993) believed that the sedimentary cover of the Lushun-Dalian 
area is characterized by the nearly E-W trending fold-and-thrust belts, and interpreted them as the result of the NCC-SCB collision during the Late Permian to Early Jurassic. This is further evidenced by the top-to-the-N or NE ductile shearing in the margin of the magmatic complex intruding into the southernmost of the Liaodong Peninsula and the N-directed folds and thrusts near Jinzhou, but the age of this N-S shortening event was constrained to be Early-Middle or Late Triassic (Lin et al., 2007, 2008). Based on the detailed mapping, Wang et al. (2000a, 2000b) considered that the main structural framework of the Lushun-Dalian area resulted from the superimposition of the N-S compression and the E-W compression. The former is characterized by a series of E-W trending large overturned and recumbent folds and was interpreted as the result of the NCC-SCB collision in Triassic (i.e. Indonisian). The later is dominated by an intense top-to-the-NW layer-parallel ductile shearing in the weak layers, such as the Nanfen Formation and the lower part of the Qiaotou Formation. The E-W compression also mylonitized the margin of the Yinjiacun magmatic complex and was interpreted as the structural response to the NW-ward subduction of Paleo-Pacific plate below eastern China in the Early Jurassic. However, Wang et al. (2001) proposed a contrary viewpoint that the E-W compression was older than the N-S compression, but the geodynamic setting of it was not discussed. By analyzing the meso- to macroscopic fold interference patterns of the sedimentary layers, Yang et al. (2011) suggested that the South Liaodong Peninsula experienced simultaneous orogen-normal (NW-SE) and orogen-parallel (NE$\mathrm{SW}$ ) shortening in one single phase of compression during the Triassic NCC-SCB collision. In summary, three problems can be concluded from the overview of the 
111

112

previous work: (1) The N-S or NE-SW compression of the Lushun-Dalian area was commonly considered as the result of the NCC-SCB collision, but its timing varies from Late Permian to Early Jurassic and needs to be more precisely constrained; (2) The timing, superimposition relationship with the NE-SW compression and the geodynamic setting of the E-W or NW-SE compression are still highly contraversial; (3) The deformation of the magmatic complex intruding into the southernmost of the Liaodong Peninsula is still unclear.

To resolve the above problems and better constrain the tectonic evolution of the Dabie-Sulu orogenic belt, we carried out a detailed structural field survey in the Lushun-Dalian area and mapped the magmatic complex at 1:2000 scale. By combining the structural data with available geochronological data, we aim to: (1) clarify the deformation history of the Lushun-Dalian area during Mesozoic, (2) provide structural constraints on the tectonic framework in the southern margin of the NCC, (3) compare the structures of the Lushun-Dalian area with its surrounding areas to unravel the Mesozoic tectonic evolution of the eastern NCC.

\section{Regional Geology}

The Liaodong Peninsula is bounded by the Paleozoic Central Asian Orogenic Belt to the north and faces the Yanshan fold-and-thrust belt and the Sulu UHP orogenic belt across the Bohai Sea to the northwest and the southeast, respectively (Fig. 1). It is an important part of the eastern NCC and consists of an old basement mainly formed by Neoarchean TTG gneisses and Paleoproterozoic highly metamorphosed rocks (Luo et al., 2004; Faure et al., 2004; Wan et al., 2012; Li et al., 2017). The basement is 
unconformably overlain by a thick, weakly metamorphosed to unmetamorphosed sedimentary cover that consists, from bottom to top, of: (1) Late Mesoproterozoic to Early Neoproterozoic shallow marine clastic rocks and platform-shelf carbonate rocks (Fig. 2b; Yang et al., 2011); (2) Cambrian to Early Ordovician platform-shelf carbonate rocks (Fig. 2b; Yang et al., 2011; Qiu et al., 2018); (3) Late Carboniferous to Permian shallow marine clastic rocks alternating with terrigenous coal-bearing rocks (Fig. 2b; Yang et al., 2011; Qiu et al., 2018). All these sedimentary series were deformed during the Mesozoic and unconformably overlain by Middle-Late Jurassic to Early Cretaceous terrigenous rocks alternating with volcanic rocks (Fig. 2b; Wang et al., 2000a; Qiu et al., 2018).

Like the other part of the eastern NCC, the Liaodong Peninsula also experienced the continent-scale NW-SE extension during the Early Cretaceous that is widely considered to be the climax of destruction of the NCC (Zhu et al., 2012; Lin and Wei, 2018). The extension is expressed by: (1) the emplacement of voluminous granitic rocks of the Early Cretaceous (Wu et al., 2005a), (2) the development of small half graben basins filled with the Early Cretaceous terrigeous rocks and volcanic rocks (Shen et al., 2011; Liu et al., 2013), and (3) the formation of a metamorphic core complex in the South Liaodong Peninsula, also known as the Liaonan MCC (Fig. 2a; Liu et al., 2005, 2011b, 2013; Lin et al., 2007, 2008). Top-to-the NW or SE extensional shearing is documented by various kinematic indicators in the detachment fault zones of the Liaonan MCC (Liu et al., 2005, 2011b, 2013; Lin et al., 2007, 2008). The duration of extension is constrained by abundant geochronological data from the volcanic rocks of the 
supradetachment half graben basins, the mylonites of the detachment fault zones, the syntectonic granite plutons, and various veins to be $135-107 \mathrm{Ma}$, with a peak at $126 \mathrm{Ma}$ (Yin and Nie, 1996; Wu et al., 2005a; Yang et al., 2007a; Ji et al., 2009; Lin et al., 2011; Wang et al., 2011a, 2012; Liu et al., 2011b, 2013; Shen et al., 2011; Lin and Wei, 2018). In addition, numerous Middle-Late Jurassic granitic plutons of various sizes and minor Late Triassic plutons are also distributed in the Liaodong Peninsula (Wu et al., 2005b, 2005c; Yang et al., 2007b, 2007c).

In the South Liaodong Peninsula, despite the important modification by the Early Cretaceous extension, pre-Cretaceous multiphase compressional deformation is well preserved in the thick sedimentary strata surrounding the Liaonan MCC (Fig. 2a; Xu et al., 1991; Yin and Nie, 1993, 1996; Wang et al., 2000a, 2000b, 2001; Yang et al., 2002; Lin et al., 2007, 2008). In particular, the structures of the Lushun-Dalian area south of the Jinzhou city formed a complex fold interference pattern (Fig. 3a; Yang et al., 2011). The sedimentary strata of the Lushun-Dalian area were deposited during 1056-924 Ma (Yang et al., 2012; Zhang et al., 2016), and contains two main sequences separated by a depositional hiatus (Fig. 2b; Yang et al., 2011). The upper and lower sequences are mainly composed of carbonate rocks and shallow marine clastic rocks (for the detailed lithological contents of Formations see Fig. 2b), and occupy the northern and southern parts of the Lushun-Dalian area, respectively (Fig. 3a). The clastic rocks and the argillaceous limestone were metamorphosed under greenschist facies conditions into schists, phyllite, slate and quartzite (Xu et al., 1991; Wang et al, 2000b). In the southernmost tip of the Liaodong Peninsula, the sedimentary strata were intruded by a 
crescent-shaped magmatic complex, here named the Yinjiacun complex, and overlain by Early Cretaceous volcanic rocks (Fig. 3a; Wang et al, 2000a, Yang et al., 2011). The Yinjiacun complex occupies about $10 \mathrm{~km}^{2}$ and consists of syenite and gabbro (Fig. 3a), the age of which were dated to be Late Triassic (Wang et al., 2002; Wu et al., 2005c).

\section{Structural analysis}

The structure in the sedimentary cover of the Lushun-Dalian area is characterized by folds and ductile shear zones (Xu et al., 1991; Wang et al., 2000a, 2000b, 2001; Yang et al., 2002, 2011; Lin et al., 2007, 2008). Our detailed regional structural fieldwork allowed us to recognize two deformation events on the basis of structural styles from the outcrops, and fold interference patterns from the map view. For the convenience of description, we divided the sedimentary cover of the Lushun-Dalian area into three structural layers based on lithology and structural pattern: (1) The lower competent layer, including the Yongning Formation and the lower part of the Diaoyutai Formation which consists of several kilometers thick sandstone and conglomerate (Fig. 2b; LBGMR, 1989), is characterized by large open folds without axial planar cleavage (Wang et al., 2000a, 2000b, 2001), and only exposed in several localities as anticlines (Fig. 3a); (2) the middle incompetent layer, composed of schist, phyllite, slate, and thin quartzite metamorphosed in greenschist facies conditions from mudstone, pelitic siltstone, siltstone and thin sandstone belonging to the upper part of the Diaoyutai Formation, Nanfen Formation, and the lower part of the Qiaotou Formation, occupies almost $40 \%$ of the whole Lushun-Dalian area, with a thickness larger than $2 \mathrm{~km}$ (Fig. 2b, 3a; LBGMR, 1989); (3) the upper competent layer, more than $3 \mathrm{~km}$ thick, composed 
of thick sandstone belonging to the upper part of the Qiaotou Formation and carbonates belonging to the Formations of Changlingzi, Ganjingzi, Nanguanling and Yingchengzi, occupies more than $40 \%$ of the Lushun Dalian area (Fig. 2b, 3a; LBGMR, 1989). The structure of the upper competent layer is characterized by NW- and NE-verging kmscale recumbent or overturned folds (Fig. 3b, 3c, 3d). These two nearly perpendicular structural trends define a complex fold interference pattern (Fig. 3a; Yang et al., 2002, 2011).

\section{1. $D_{1}$ Deformation}

Except for the Early Cretaceous volcanic rocks, all the lithotectonic units of the Lushun-Dalian area were involved in the $\mathrm{D}_{1}$ deformation event. In the southwestern end of the Liaodong Peninsula, the Late Triassic Yinjiacun complex and its country rocks were concurrently foliated, even mylonitized (Fig. 4a, 4b). Although the dip of the $\mathrm{S}_{1}$ foliation changed from $\mathrm{SW}$ to $\mathrm{NW}$ during the later structural event, the $\mathrm{L}_{1}$ lineation consistently trends NE-SW (Fig. 4c, 4d). Along $\mathrm{L}_{1}$, various kinematic indicators showing a top-to-the-NE shear sense can be clearly observed in the mylonitized gabbro and syenite, such as the sigma- or delta-type K-feldspar porphyroclasts (Fig. 4e). A NE-directed ductile thrust fault zone located at the boundary between the complex and its country rocks can be inferred from the SW-dipping $\mathrm{S}_{1}$ foliations and the top-to-the-NE kinematic indicators along the $\mathrm{L}_{1}$ lineations. The complex was thrusted northeastward from the middle-lower crust level over the lowgrade metasedimentary rocks (Lin et al., 2007).

In the sedimentary rocks, $\mathrm{D}_{1}$ is mainly expressed by $\mathrm{F}_{1}$ folds, the hinges of which are 
subhorizontal and trend consistently NW-SE (Fig. 3e). The style of $F_{1}$ and the development of an axial planar cleavage $S_{1}$ change regularly from south to north. Specifically, in the country rocks of the Yinjiacun complex, the original bedding $\mathrm{S}_{0}$ was almost completely transposed into $\mathrm{S}_{1}$ which dips to the $\mathrm{SW}$ with high angle, only a few small SW-plunging isoclinal folds can be observed in the schist (Fig. 4f). As the hinges of these folds are parallel to the $\mathrm{L}_{1}$ lineation, we prefer to interpret them as a-type folds formed during the top-to-the-NE shearing. In the incompetent layer, $\mathrm{F}_{1}$ are mainly NEverging or nearly upright folds with penetrative SW-dipping or subvertical axial planar cleavage $S_{1}$ (Fig. 3e, 4g). Notably, $F_{1}$ and $S_{1}$ in this unit are only preserved in the mudstone and siltstone near the lower sandstone anticlines (Fig. 3a). In the upper competent layer, $\mathrm{F}_{1}$ forms a series of $\mathrm{km}$-scale NE-verging overturned or recumbent folds (Fig. 3a, 3b). The axial planar cleavage $S_{1}$ is rarely developed in this unit. Upward and northward continuously, km-scale NE-verging inclined folds and kink folds are the main fold types in the Cambrian-Ordovician carbonate rocks (Fig. 2a, 4h). No axial planar cleavage $S_{1}$ is observed in this unit, conversely, the NE-directed brittle thrust faults become common (Fig. 4h).

\section{2. $D_{2}$ Deformation}

The $\mathrm{D}_{2}$ deformation overprinted the $\mathrm{D}_{1}$ fabrics and formed various types of folds and fold interference patterns in different lithotectonic units. In the lowest Yinjiacun complex and its country rocks, the SW-dipping foliation $\mathrm{S}_{1}$ and the NE-directed ductile thrust fault were folded and formed a kilometer-scale SW-plunging vertical fold $\mathrm{F}_{2}$ (see details in section 3.3). 

intraformational recumbent folds $F_{2}, S_{2}$ foliation and $L_{2}$ lineation. The hinges of $F_{2}$ are commonly subhorizontal and consistently trend NE-SW (Fig. 3f). The $\mathrm{S}_{2}$ foliation is actually the penetrative axial planar cleavage of $F_{2}$. This can be inferred from the $S_{0-}$ ${ }_{1} / \mathrm{S}_{2}$ cross-cutting relationships which are rarely preserved in the intrafolial folds of slates and the intraformational recumbent folds of thin sandstones (Fig. 5a). The $\mathrm{S}_{0-1}$ surface was pervasively transposed into $S_{2}$ which is subparallel and oblique to the $S_{0-1}$ in the limbs and hinge zones of $F_{2}$ folds, respectively (Fig. 5a). Maybe due to a late reworking by later deformation events, $\mathrm{S}_{2}$ dips to various directions with low angles (Fig. 3f), but the mineral and stretching lineation $\mathrm{L}_{2}$ marked by the preferred orientation 253 of quartz aggregates, sericite and chlorite clots consistently trend NW-SE (Fig. 3f, 5b). the siltstone near the lower sandstone anticlines (Fig. 3a).

Along $\mathrm{L}_{2}$, top-to-the-NW shearing can be inferred from the sigmoidal quartz boudins in outcrops (Fig. 5c). In thin sections, cut perpendicular to the $\mathrm{S}_{2}$ foliation and parallel to the $\mathrm{L}_{2}$ lineation, the same shear sense is indicated by sigma-type quartz porphyroclasts (Fig. 5d). All these features suggest that the incompetent layer is a huge folded layer formed under a subhorizontal intense ductile shearing. It is noteworthy that no $L_{1}$ lineation developed in this unit and the subvertical $S_{1}$ foliation is only found in In the upper sandstone layer, a series of km-scale overturned $F_{2}$ folds with $\mathrm{NW}$ vergence are outlined by the alternation occurrence of normal and reversed strata (Fig. $3 \mathrm{a}, 3 \mathrm{c})$. These folds refolded the $\mathrm{F}_{1}$ ones, and formed a basin structure around the 
rocks, the overturned and recumbent folds $F_{1}$ were also refolded by the $F_{2}$ and formed the map-scale SW-plunging folds which are well exposed in the Huanglongwei and Heishishan areas (Fig. 3a, 3d). Another striking compressional structures are a set of small-scale NE-SW trending thrust faults developed in the area between Yinggeshi and Huangnichuan (Fig. 3a, 3d; Yang et al., 2011). These thrust faults dip to NW with low angles and can cut through the lower thick sandstone, although most of them die out into the incompetent layer. They juxtapose the older strata over the younger one, i.e. the upper sandstone over the argillaceous limestone of the Changlingzi Formation near Yinggeshi, the incompetent layer over the upper sandstone between Yinggeshi and Huangnichuan, the lower sandstone over the incompetent layer near Huangnichuan, and indicate a sense of SE-directed thrusting (Fig. 3a, 3d).

\subsection{Polyphase deformation in the Yinjiacun complex}

The crescent-shaped Yinjiacun complex exposed at the southernmost Liaodong Peninsula had been considered as a massive body with a mylonitized margin for a long time (Wang et al., 2000a; Lin et al., 2007). Wang et al. (2000a) interpreted the mylonitized margin as the result of a regional NW-SE compression. While Lin et al. (2007) recognized pervasive SW-dipping foliation containing SW-plunging lineation in the margins of gabbro and the country rocks. Along the lineation, top-to-the-NE ductile shearing was indicated by the asymmetric porphyroclasts of feldspar and amphibole. Accordingly, Lin et al. (2007) thinked that the margins of gabbro and the country rocks were mylonitized in a NE-directed compression and inferred that there existed a ductile thrust fault between the gabbro and the country rocks. The ductile thrust fault dips to 
SW and juxtaposes the gabbro over the country rocks and they were then intruded by the undeformed syenite. Apparently, the Yinjiacun complex plays an important role in understanding the tectonic evolution of the South Liaodong Peninsula, but the deformation of it has not been clearly investigated.

In order to clarify the deformation of the Yinjiacun complex, we carried out a detailed field structural mapping of the magmatic complex at scale of 1: 2000 and obtained several new findings as follows: (1) The syenite is predominant and distributed throughout almost the whole complex (Fig. 6a). The gabbro is only continuously distributed in the SE part of the complex and encompassed by the syenite as decameter to hectometer-scale blocks in other parts of the complex (Fig. 6a); (2) Both the syenite and gabbro intruded into the country rocks and were together intensely foliated, even mylonitized (Fig. 4a, 4b). The ductile thrust fault can be extended into the boundary between the syenite and the country rocks (Fig. 6a). The intrusive relationships between the complex and the country rocks are not only expressed in the outcrops, but also in the map view in which the limestone of the Nanguanling Formation was separated into two parts by the syenite (Fig. 6a). Marble can be observed in the outcrops at the boundary between the syenite and the limestone; (3) In the country rocks, from the NE toward the SE, the dip of the foliation together with the boundary ductile thrust fault changes regularly from SW to NW with high angle (Fig. 6a, 6b). The foliation trajectory and the bended thrust fault outline a km-scale SW-plunging subvertical fold; (4) The complex was heterogeneously deformed and several ductile shear zones have been mapped. The syenite and gabbro in the ductile shear zones were also intensely foliated 
and even mylonitized, while those between the ductile shear zones are almost massive (Fig. 6a). The dip of foliation in the ductile shear zones exhibits a similar change to those of the country rocks. The foliation trajectories of the complex outlines numerous SW-plunging subvertical folds with smaller wavelengths (Fig. 6a); (5) Although the foliation attitude in both the complex and its country rocks changes regularly, the lineation contained on the foliation consistently plunges down to the SW with moderate to gentle angles (Fig. 4c, 4d, 6a, 6b). Along the lineation, top-to-the-NE shearing is indicated by the sigma- or delta-type K-feldspar porphyroclasts in the mylonitized syenite (Fig. 4e).

The above observations suggest that the Yinjiacun complex and its country rocks record two stages of deformation. The first one deformed the complex into several SWdipping ductile shear zones, formed the SW-plunging lineation and the NE-directed thrust fault (Fig. 6c). The geometric and kinematic features are similar to those of the sedimentary cover in other parts of the Lushun-Dalian area. Therefore the first stage of deformation recorded in the complex corresponds to the $\mathrm{D}_{1}$ deformation observed in the sedimentary cover. The second one folded the foliation of ductile shear zones and the thrust fault, the dips of which turn from SW to NW, and formed the large steeply plunging subvertical folds in map view, together with the numerous small parasitic plunging subvertical folds in the complex. A large NW-verging fold is also indicated by the contrasting occurrence of the sandstone beds in NW and SE flanks of the Laotieshan (Fig. 6d). This indicates that the second stage of deformation recorded in the complex corresponds to the $\mathrm{D}_{2}$ deformation in the sedimentary cover. 


\section{Geochronological constraints}

332

The field observations and structural analysis presented above suggest that the Yinjiacun complex recorded the $\mathrm{D}_{1}$ and $\mathrm{D}_{2}$ deformation of the Lushun-Dalian area. Therefore the precise ages of the syenite and gabbro of the complex can well constrain the lower limit of $\mathrm{D}_{1}$ and $\mathrm{D}_{2}$. However, the emplacement age of the complex is poorly constrained. The available ages of the gabbro and syenite were commonly provided without detailed sample descriptions and experiment procedures, and vary widely by different dating methods. For example, the LA-ICP-MS zircon U-Pb age of the syenite provided by Wu et al. (2005c) is $219 \pm 1 \mathrm{Ma}$, older than the TIMS single zircon U-Pb age $214.3 \pm 1.5 \mathrm{Ma}$ of the gabbro (Yang et al., 2011). However, the TIMS single zircon $\mathrm{U}-\mathrm{Pb}$ age of the syenite provided by Yang et al. (2011) is $208.8 \pm 1.3 \mathrm{Ma}$, younger than that of the gabbro. The difference between the two ages of the syenite is about $10 \mathrm{Ma}$, therefore the ages of the syenite and gabbro remain to be improved. One gabbro sample (DL101) and one syenite sample (LS04A) were collected from the complex for zircon SIMS U-Pb dating. Sample locations are marked in Fig. 6a.

\subsection{Analytical techniques}

The samples were processed by crushing, heavy liquid and subsequent magnetic separations. Zircons were hand-picked and mounted in epoxy mounts together with zircon standards, and then polished to section the crystals in half for analysis. All zircons were photographed in transmitted and reflected light, and the cathodoluminescence (CL) image in order to reveal their internal structures (Fig. 7a). The mount was vacuum-coated with high-purity gold for SIMS analysis. Measurements 
353

354

355

of $\mathrm{U}, \mathrm{Th}$ and $\mathrm{Pb}$ isotopes were conducted using a Cameca IMS-1280 at the Institute of Geology and Geophysics, Chinese Academy of Sciences (IGGCAS), Beijing. The instrument description and analytical procedure can be found in Li et al. (2009b). The beam spot was about $20 \times 30 \mu \mathrm{m}$ in size, and positive secondary ions were extracted with a $10 \mathrm{kV}$ potential. Standard zircons Plešovice (Sláma et al., 2008) and Qinghu (Li et al., 2013) were alternately analyzed with unknown zircons from the samples. Measured compositions were corrected for common $\mathrm{Pb}$ using the non-radiogenic ${ }^{204} \mathrm{~Pb}$. Uncertainties of individual analyses are reported at $1 \sigma$ in Table 1 . The concordia diagrams of $\mathrm{U}-\mathrm{Pb}$ data are shown in Fig. $7 \mathrm{~b}$ and $7 \mathrm{c}$, where weighted mean ${ }^{206} \mathrm{~Pb} /{ }^{238} \mathrm{U}$ ages or concordia ages are quoted at either $95 \%$ confidence interval. Data reduction was carried out using the Isoplot program (Ludwig, 2003).

\subsection{Analytical results}

\subsubsection{Sample DL101}

Sample DL101 is a dark gray weakly foliated gabbro that is mainly composed of medium- to coarse-grained plagioclase, pyroxene, hornblende, biotite and minor quartz. Zircons from sample DL101 are commonly euhedral, colorless and transparent, ranging from 120 to $400 \mu \mathrm{m}$ in length with aspect ratios of 1:1-3:1. They show conspicuous oscillatory zoning and no inherited cores under CL (Fig. 7a). Eighteen zircons were analyzed, their $\mathrm{U}$ and Th contents range from 120 to $722 \mathrm{ppm}$, and 130 to $1216 \mathrm{ppm}$, respectively. The $\mathrm{Th} / \mathrm{U}$ ratios of 0.44 to 1.75 (Table 1) suggest a magmatic origin. The concordant age of $211.0 \pm 1.5 \mathrm{Ma}(\mathrm{MSWD}=0.064)$ represents the crystallization time of the gabbro (Fig. 7b). 


\subsubsection{Sample LSO4A}

Sample LS04A is a light red massive syenite that is mainly composed of medium- to fine-grained K-feldspar, plagioclase, quartz and minor biotite. Zircons from sample LS04A are mostly euhedral, colorless and transparent, ranging from 100 to $400 \mu \mathrm{m}$ in length with aspect ratios of $1: 1-3: 1$. Most grains are characterized by magmatic growth zonation in CL images (Fig. 7a). Eighteen zircons were analyzed, their $\mathrm{U}$ and Th contents range from 127 to $597 \mathrm{ppm}$ and 70 to $383 \mathrm{ppm}$, respectively, with $\mathrm{Th} / \mathrm{U}$ ratios of 0.40 to 0.86 (Table 1), indicating a magmatic origin. The analyses yield a concordia age of $214.7 \pm 1.5 \mathrm{Ma}(\mathrm{MSWD}=0.036)$, interpreted as the crystallization age of the syenite (Fig. 7c).

\section{Discussion}

\subsection{Polyphase deformation and its geochronological constraint}

As presented above, the Lushun-Dalian area experienced two stages of deformation which are recorded in every unit except for the Early Cretaceous volcanic rocks (Fig. 8). $\mathrm{D}_{1}$ is not only well recorded in the pre-Mesozoic lithotectonic units of the South Liaodong Peninsula (Wang et al., 2000a, 2000b; Yang et al., 2002, 2011; Lin et al., 2007, 2008), but also in those of the Changshan islands east of the Liaodong Peninsula (Fig. 2a; Ren and Lin, 2019). The NE-verging $F_{1}$ folds and NE-directed thrust faults in the metasedimentary rocks suggest that $\mathrm{D}_{1}$ is a top-to-the-NE compressional event. From the SW to the NE, the development of the axial planar cleavage $S_{1}$ of the fold $F_{1}$ varies from penetrative slaty cleavage to less spaced one and disappears northeastward. The thrust fault changes from ductile fault zones to brittle ones. The 
397

398

399

400

401

402

403

404

405

406

407

408

409

410

411

412

413

414

415

SW-plunging $\mathrm{L}_{1}$ lineation is only exhibited on the $\mathrm{S}_{1}$ foliation of the Yinjiacun complex and its country rocks, but disappears in the sedimentary series far away from the Yinjiacun complex. All these structural features suggest that the $\mathrm{D}_{1}$ intensity decreases from the southwest to the northeast (Yang et al., 2002, 2011).

The $\mathrm{D}_{2}$ deformation is characterized by a subhorizontal foliation $\mathrm{S}_{2}$, a NW-SE trending mineral and stretching lineation $\mathrm{L}_{2}, \mathrm{NW}$-verging folds $\mathrm{F}_{2}$ and $\mathrm{SE}$-directed brittle thrust faults. A subhorizontal ductile shearing can be inferred from the welldeveloped $\mathrm{S}_{2}, \mathrm{~L}_{2}$ and the top-to-the-NW kinematic indicators in the incompetent layer. The abundant intrafolial and intraformational recumbent folds $F_{2}$ with subhorizontal NE-SW trending hinges were formed during the $\mathrm{D}_{2}$ ductile shearing. Their axial planar cleavage $\mathrm{S}_{2}$ almost completely transposed the $\mathrm{S}_{0-1}$ surfaces which are rarely preserved, except in the residual hinge zones of the folds (Fig. 5a). Therefore the incompetent layer is actually a decollement zone above which a series of NW-verging $\mathrm{km}$-scale recumbent folds developed in the upper competent layer (Fig. 3c), and below which large open folds and slightly inclined folds with NW vergence developed in the lower competent layer (Fig. 3c, 3d, 6d). All these structural elements suggest that $\mathrm{D}_{2}$ is a top-to-the-NW compressional event. Another significant compressional structures are the arrays of NESW trending thrust faults in the areas from Yinggeshi to Huangnichuan, however, their kinematics are top-to-the-SE (Fig. 3d; Wang et al., 2002; Yang et al., 2011). These SEdirected thrust faults were considered as the secondary structures during the formation of the NE-SW trending folds under the NW-SE or E-W compression (Wang et al., 2002). Therefore, we prefer to interpret them as results of the back-thrusting during the lasting 
NW-directed compression. It is worth noting that the occurrence of axial planes of the original NW-verging recumbent folds in the Heishishan and Huanglongwei were also changed from subhorizontal to slightly dipping to NW during the stage of backthrusting (Fig. 3d).

The superposition of $D_{2}$ on $D_{1}$ is clearly expressed by the $F_{2}$ folds refolding the $F_{1}$ ones in the lower and upper competent units and produced numerous km-scale SWplunging folds. However, in the incompetent layer, only the subhorizontal $\mathrm{S}_{2}$ foliation and NW-SE trending $\mathrm{L}_{2}$ lineation are observed. The SW-dipping axial planar cleavage $\mathrm{S}_{1}$ is commonly preserved in the siltstone near the northeast limb of the lower sandstone anticlines (Fig. 3a, 8). One reasonable interpretation for this phenomenon is that the intense top-to-the-NW subhorizontal $\mathrm{D}_{2}$ ductile shearing erased the $\mathrm{D}_{1}$ structures. Toward the sandstone anticlines, the subhorizontal ductile shearing weakened and the SW-dipping $\mathrm{S}_{1}$ cleavages were well preserved and exposed to the surface during the uplift of these anticlines (Fig. 8). In the incompetent layer just to north of the Yinjiacun complex, $\mathrm{S}_{1}$ was not erased by the ductile shearing of $\mathrm{D}_{2}$ deformation, and only bended under the $\mathrm{D}_{2}$ compressional stress (Fig. 6a, 8). This mainly depends on the rock associations and the striking difference of the mechanical properties among them. As a product of the $\mathrm{D}_{1}$ deformation, the incompetent layer next to the Yinjiacun complex was distributed in a narrow strip and sandwiched between the wider and more rigid Yinjiacun complex and the thick sandstone of Laotieshan (Fig. 6a, 8). While the thick incompetent layer far away from the Yinjiacun complex was distributed in a vast plane and sandwiched between thick sandstone and carbonate rocks (Fig. 8). From a 
mechanical point of view, the rigidity of the former rock associations is much higher than that of the latter. Thus, the former rock associations are more difficult to be deformed under the same compressional stress than the latter. Consequently, $\mathrm{S}_{1}$ in the incompetent layer next to the Yinjiacun complex was well preserved in the $\mathrm{D}_{2}$ deformation, but was almost erased in the incompetent layer far away from the Yinjiacun complex (Fig. 8).

Our SIMS U-Pb dating results reveal that the emplacement ages of the syenite and gabbro are $214.7 \pm 1.5 \mathrm{Ma}$ and $211.0 \pm 1.5 \mathrm{Ma}$, respectively. Considering that the syenite and gabbro were all deformed by both $\mathrm{D}_{1}$ and $\mathrm{D}_{2}$ (Fig. 8), the timing of which can be inferred to be after 211Ma. According to Ren and Lin (2019), the NE-SW compressional structures of the Changshan islands and the Lushun-Dalian area were formed in one single deformation event, i.e. the $\mathrm{D}_{1}$ deformation in this study. The $\mathrm{D}_{1}$ event did not rework the granite pluton exposed on the Guanglu and Guapi islands, the age of which was determined by the SIMS zircon $\mathrm{U}-\mathrm{Pb}$ method to be $165 \mathrm{Ma}$ (Ren and Lin, 2019). Therefore, the $\mathrm{D}_{1}$ deformation of the Lushun-Dalian area and the Changshan islands occurred before 165 Ma. Wang et al. (2002) reported a muscovite ${ }^{40} \mathrm{Ar} /{ }^{39} \mathrm{Ar}$ age of $192.7 \pm 0.1 \mathrm{Ma}$ from the micaschist north of the Yinjiacun complex and interpreted it as the age of the N-S compression in the South Liaodong Peninsula. In the well known indentation model of Yin and Nie (1993), the collision between NCC and SCB lasted until $188 \mathrm{Ma}$ and caused the greatest NE-SW shortening north of the Sulu orogenic belt. All these previous works further constrain the upper limit of the $D_{1}$ deformation to be about 190 Ma. Therefore, the $\mathrm{D}_{1}$ deformation in the South Liaodong 
Peninsula occurred between 211 and 190 Ma, i.e. the Late Triassic to Early Jurassic.

The timing of the $\mathrm{D}_{2}$ deformation can be further constrained to be after the Early Jurassic, since then the tectonic evolution of the eastern China had been controlled by the northwestward subduction of the Paleo-Pacific plate that gave rise to the NW-SE shortening during the Middle-Late Jurassic (Liu et al., 2017; Li et al., 2019; Zhu et al., 2019). The NW-SE compressional structures in the NCC derived from the shortening are characterized by the NW-or SE-directed fold-and-thrust belts and are widely distributed in the tectonic belts of Yinshan-Yanshan, Taihangshan, Luliangshan and Helanshan (Wang et al., 2008, 2011, 2015; Faure et al., 2012; Huang et al., 2015; Wang et al., 2017a; Clinkscales and Kapp, 2019). The lower limit of these compressional structures has been constrained to be about $170 \mathrm{Ma}$ (Wang et al., 2008, 2011; Dong et al., 2015; Wang et al., 2017a). Similar geometric and kinematic features suggest that the NW-SE compressional structures of the South Liaodong Peninsula were formed in the same shortening event with those of the above tectonic belts of the NCC. Thus, the lower limit of the $\mathrm{D}_{2}$ deformation in the Lushun-Dalian area occurred after $170 \mathrm{Ma}$, but earlier than the eruption of the massive volcanic rocks of the Guiyunhua Formation that is distributed in the small Late Mesozoic extensional basins throughout the South Liaodong Peninsula (Fig. 2a). The volcanic rocks of the Guiyunhua Formation, mainly andesite and rhyolite, have been precisely dated by SHRIMP and LA-ICP-MS zircon $\mathrm{U}-\mathrm{Pb}$ methods and the results suggest that the maximum eruption age of these volcanic rocks is $135 \mathrm{Ma}$ (Liu et al., 2011b; Shen et al., 2011). Consequently, the $\mathrm{D}_{2}$ deformation occurred between 170 and 135 Ma, i.e., in the Middle-Late Jurassic to earliest 


\section{Cretaceous.}

It is noteworthy that the decollement zone in the weakly metamorphosed sedimentary rocks south of Dalian city is different from the detachment fault zones of the Liaonan MCC north of Dalian city, although the NW-SE trending mineral and strecthing lineations and top-to-the-NW ductile shearing were developed in both of them. They can be distinguished from the following three aspects: (1) Occurrence and scale. The former occupies tens of $\mathrm{km}^{2}$ in a vast plane and has a thickness larger than $1.5 \mathrm{~km}$ (Fig. 2). While the latter occurs as narrow strips around the MCC and usually have a thickness of hundreds of meters (Fig. 2; Liu et al., 2005). So do the detachment fault zones around the extensional domes of the Changshan islands (Ren and Lin, 2019); (2)

Structrual levels. The former was developed in the upper crust level and only reworked the sedimentary cover. The latter was developed in the middle-lower crust level and intensely reworked not only the Archean basement, but also the Middle-Late Jurassic to Early Cretaceous granitic plutons (Liu et al., 2005; Yang et al., 2007a; Lin et al., 2008); (3) Timing. The former and the large NW-verging folds above it were uncomformably overlain by the Early Cretaceous vocalnic rocks of the Guiyunhua Formation (Fig. 3d). And the above analysis further constrains the timing of the decollement zone of the Lushun-Dalian area to be the Middle-Late Jurassic. The latter controlled the formation of the supradetachment basins which were filled with the Guiyunhua Formation and other terrigeneous deposits. The abundant ages suggest that the detachment fault zones of the Liaonan MCC was active during 135-107 Ma, i.e. the Early Cretaceous (Yang et al., 2007a; Lin et al., 2011; Liu et al., 2013). Therefore, the 
507

508

509

510

511

512

513

514

515

516

517

518

519

520

521

522

523

524

525

526

527

528

$\mathrm{D}_{2}$ deformation of the Lushun-Dalian area is not related to the Early Cretaceous extension, but a Middle-Late Jurassic compressional event.

\subsection{The structural response in the overriding plate to the NCC-SCB convergence:}

\section{the NE-SW compression}

It is well known that the Dabie-Sulu orogenic belt resulted from the Triassic convergence between NCC and SCB (Mattauer et al., 1985; Ames et al., 1993; Li et al., 1993). The continental crust of the SCB was subducted into manle and underwent an ultra-high pressure (UHP) metamorphism, then it was exhumed to the surface (Ye et al., 2000). Accompanying this process was the development of the broad fold-and-thrust belt in the northern margin of the SCB which recorded not only the syn-convergence compression but also the late convergence compression (Schmid et al., 1999; Liu et al., 2001; Ratschbacher et al., 2003; Li et al., 2009c; Liu et al., 2011a, 2012). However, such a compressional deformation had been rarely identified in the southern margin of the NCC adjacent to the Dabie-Sulu orogenic belt.

North of the Dabie orogenic belt, the southern margin of the NCC is mostly covered by the Mesozoic Hefei basin, north of which only a few NE-verging folds and NEdirected thrust faults of the Middle-Late Triassic can be observed in the Bengbu uplift (Fig. 1; Sun et al., 2004; Wang et al., 2016). In the Jiaobei massif north of the Sulu orogenic belt, the NE-SW compressional deformation was only reported in the residual weakly metamorphic sedimentary rocks (called the Penglai group; Zhu, 1993; Zhu et al., 1994; Zhu and Xu, 1994). It is characterized by NW-SE trending folds coeval with highly NE-dipping cleavages. These structures were interpreted as the result of a NE- 
SW compression related to the NCC-SCB convergence, although its timing was constrained to be the Late Carboniferous (Zhu, 1993; Zhu et al., 1994; Zhu and Xu, 1994).

Contrastingly, 100-200 km north of the Sulu orogenic belt, the NE-SW compressional deformation is unambiguously recorded in the South Liaodong Peninsula and the Changshan islands. It is commonly expressed by the NW-SE or nearly E-W trending folds and thrusts in the sedimentary cover and the top-to-the-NE ductile shearing in the basement, and considered as the structural response to the NCCSCB convergence in the overriding plate (Yin and Nie, 1993; Wang et al., 2000a, 2000b, 2001; Yang et al., 2002, 2011; Lin et al., 2007, 2008; Ren and Lin, 2019). Our field structural mapping and new SIMS zircon U-Pb ages of the Yinjiacun complex allow us to constrain the age of the NE-SW compression at 211-190 Ma, since then the PaleoPacific plate had subducted NW-ward below the eastern China (Zhou et al., 2014; Liu et al., 2017; Li et al., 2019). However, there is no genetic connection between them because the compressional direction of $\mathrm{D}_{1}$ deformation was nearly perpendicular to the subduction of the Paleo-Pacific plate. The NE-ward decreasing of the $\mathrm{D}_{1}$ deformation intensity suggests that the compressional stress derived from the SW and can only be provided by the NCC-SCB convergence. However, during 211-190 Ma, the NCC-SCB convergence had entered into a late stage. Consequently, the NE-SW compression recorded in the South Liaodong Peninsula and the Changshan islands actually belongs to a late convergence compression, rather than a syn-convergence one. 
551

552

553

554

555

556

557

558

559

560

561

562

563

564

565

566

567

568

569

570

571

572

of NCC north of the Sulu orogenic belt during the Triassic convergence, and propose the following scenario: (1) During the syn-convergence compression (254-220 Ma), the continental crust of the SCB was subducted beneath the NCC, and experienced the prograde to HP-UHP metamorphism (Liu et al., 2006; Hacker et al., 2009). Broad foldthrust belts were well developed in the northern SCB, while only narrow fold-thrust belts were developed in the southern margin of the NCC (Fig. 9a). This is consistent with the deformation asymmetry during the continent-continent collisional orogeny (Willett et al., 1993; Beaumont et al., 1996); (2) The syn-convergence extensional exhumation (220-211 Ma) brought the UHP metamorphic rocks to the middle crustal level where they experienced an amphibolite facies metamorphic overprint (Liu et al., 2006; Hacker et al., 2009). The top-to-the-NW extensional tectonics were well developed in the upper part of the subducting plate (Faure et al., 2001, 2003a; Lin et al., 2005c). Minor alkaline magmatic plutons intruded within and north of the Sulu orogenic belt (Fig. 9b; Chen et al., 2003; Guo et al., 2005; Yang et al., 2005). At the same time, the southern margin of the NCC might also be in an extensional regime and the earlier thrust faults were inversed into normal faults (Fig. 9b). (3) The postconvergence intracontinental NE-SW compression (211-190 Ma), probably caused by the lasting convergence between the NCC and SCB, mylonitized and thrusted the Yinjiacun magmatic complex over the weakly metamorphic sedimentary rocks of the South Liaodong area. A series of NE-verging folds and NE-directed thrust faults in the sedimentary rocks of the southern margin of the NCC developed (Fig. 9c). The new scenario suggests that the structural response of the overriding plate to the continent- 
continent collisional orogeny might be more complex than the previously studied. It might not always be compession throughout the convergence of two continents like that of the indentation model proposed by Yin and Nie (1993), nor be compression only in the syn-convergence stage, but be the alternation of compression and extension.

\subsection{The structural response of the NCC to the subduction of the Paleo-Pacific plate:}

\section{the NW-SE compression}

The NW-SE compressional deformation in the sedimentary cover of the LushunDalian area has been identified for a long time, however, controversies still exist in its origin, timing and relationship with the NE-SW compression (Xu et al., 1991; Wang et al., 2000a, 2000b; Yang et al., 2011). Our structural and geochronological data suggest that the NW-SE compression in the Lushun-Dalian area occurred in the Middle-Late Jurassic and superimposed on the Late Triassic-Early Jurassic NE-SW compression. Actually, the NW-SE Middle-Late Jurassic compression was also developed in the neighbouring areas of the Lushun-Dalian area. Near the Wafangdian city, the SEdirected thrusting of the Cambrian limestone over the Middle Jurassic clastic rocks exposed in the Zhayao tectonic window was considered as the result of the NW-ward subduction of the Paleo-Pacific plate beneath the NCC during the Late Jurassic to the earliest Cretaceous (Fig. 2a; Qiu et al., 2018). In the weakly metamorphic sedimentary rocks of the Penglai Group in the Jiaobei massif, the NW-SE compressional deformation mainly expressed by NE-SW trending folds that refolded the earlier NWSE trending folds and cleavages did not rework the Early Cretaceous volcanic rocks and was loosely constrained to occur in the Jurassic (Zhu, 1993; Zhu and Xu, 1994). 
Middle-Late Jurassic was more developed (Fig. 1; Davis et al., 2001; Zhang et al., 2007;

597 Faure et al., 2012; Dong et al., 2015; Wang et al., 2017b, 2018), from the eastern segment of the Yanshan tectonic belt in the western Liaoning province and eastern Hebei province of the eastern NCC (Yang et al., 2001; Hu et al., 2010), through the 600 Western Hills of Beijing and the northern Taihangshan of the central NCC (Wang and Li, 2008; Wang et al., 2011b; Clinkscales and Kapp, 2019), to the Helanshan tectonic belt in the western margin of the Ordos basin (Darby and Ritts, 2007; Huang et al., 603 2015). It superimposed on the earlier N-S compression in the Yanshan orogenic belt 604 and changed its tectonic trends from E-W to NE and NNE (Wang et al., 2015). The driving mechanism of the compression was commonly attributed to the NW-ward subduction of the Paleo-Pacific plate beneath the eastern China in the Middle-Late Jurassic (Dong et al., 2015; Wang et al., 2017b, 2018). Corresponding to this process, 608 the compressional stress transmitted from the eastern margin of the NCC to its western interior, and a series of fold-thrust belts with NW vergence were developed upon a basal decollement zone located between the crystalline basement and the overlying sedimentary rocks (Wang et al., 2015). The intensity and age of the NW-SE compression became weaker and younger toward the interior of the NCC, respectively 613 (Wang et al., 2017b).

614 Compared to the NCC west of the Tan-Lu fault, the Lushun-Dalian area of South Liaodong Peninsula exposes more ductile structures with a top-to-the-NW sense of shear. The intensely deformed thick incompetent layer located at the base of the Middle- 
617

618

619

620

621

622

623

624

625

626

627

628

629

630

631

632

633

634

635

636

637

638

Upper Proterozoic metasedimentary rocks are probably the SE extension of the subhorizontal decollement zone developed in the SE part of the Yanshan orogenic belt (Wang et al., 2015). Above this subhorizontal decollement zone, NW-vergent folds and brittle thrusts were widely developed upward and westward, and intensely reworked the earlier E-W trending structures (Fig. 8, 9d). The similarity in age and kinematics combined with the eastward strengthening of deformation intensity lead us to consider the NW-SE deformation of Lushun-Dalian area as the tectonic response to the NWward subduction of the Paleo-Pacific plate beneath the NCC in the Middle-Late Jurassic, during which a significant tectonic transformation from the E-W trending Tethysian domain to the NE-SW trending Pacific domain occurred (Wang et al., 2015).

\section{Conclusion}

The Lushun-Dalian area of the South Liaodong Peninsula is a key area to decipher the Mesozoic tectonic evolution of eastern NCC. Our new structural and geochronological data show that this area experienced two stages of compressional deformation. The $\mathrm{D}_{1}$ deformation, characterized by the top-to-the-NE ductile shearing, NE-verging folds with the SW-dipping axial planar cleavages $\mathrm{S}_{1}$ and the NE-directed thrust faults, was the tectonic response to the convergence between NCC and SCB during the Late Triassic to Early Jurassic. The $\mathrm{D}_{2}$ deformation, dominated by the topto-the-NW ductile shearing, NW-verging folds and SW-plunging folds, was the structural response to the NW-ward subduction of the Paleo-Pacific plate beneath the NCC during the Middle-Late Jurassic. Field observations and mapping suggest that the top-to-the-NW shearing erased the $\mathrm{D}_{1}$ structures in the thick incompetent layer. The $\mathrm{D}_{2}$ 
NW-SE shortening reworked the earlier E-W trending structures in the lower and upper competent units, and formed a series of $\mathrm{km}$-scale SW-plunging folds. The superimposition of $\mathrm{D}_{2}$ on $\mathrm{D}_{1}$ recorded a significant tectonic transformation from the EW trending Tethysian domain to the NE-SW trending Pacific domain.

\section{Acknowledgements}

This study was funded by the National Key R\&D Program of China (Grant Numbers 2016YFC0600102 and 2016YFC0600401) and NSFC (91855212, 91755205, $41472193)$.

\section{References}

Ames, L., Tilton, G.R., and Zhou, G.Z., 1993, Timing of collision of the Sino-Korean and Yangtse cratons: U-Pb zircon dating of coesite-bearing eclogites: Geology, v. 21, p. 339-342.

Beaumont, C., Ellis, S., Hamilton, J., and Fullsack, P., 1996, Mechanical model for subductioncollision tectonics of Alpine-type compressional orogens: Geology, v. 24, no. 8, p. 675-678.

Castellarin, A., and Cantelli, L., 2000, Neo-Alpine evolution of the Southern Eastern Alps: Journal of Geodynamics, v. 30, p. 251-274.

Ceriani, S., and Schmid, S.M., 2004, From N-S collision to WNW-directed post-collisional thrusting and folding: Structural study of the Frontal Penninic Units in Savoie (Western Alps, France): Eclogae Geologicae Helvetiae, v. 97, p. 347-369.

Charles, N., Gumiaux, C., Augier, R., Chen, Y., Zhu, R., and Lin, W., 2011, Metamorphic core complex vs. synkinematic pluton in continental extension setting: insights from key structures (Shandong Province, eastern China): Journal of Asian Earth Sciences, v. 40, p. 261-278.

Charles, N., Augier, R., Gumiaux, C., Monié, P., Chen, Y., Faure, M., and Zhu, R.X., 2013, Timing, duration and role of magmatism in wide rift systems: Insights from the Jiaodong Peninsula (China, East Asia): Gondwana Research, v. 24, p. 412-428.

Chen, J.F., Xie, Z., Li, H.M., Zhang, X.D., Zhou, T.X., Park, Y.S., Ahn, K.S., Chen, D.G., and 
Zhang, X., 2003, U-Pb zircon ages for a collision-related K-rich complex at Shidao in the Sulu ultrahigh pressure terrane, China: Geochemical Journal, v. 37, p. 35-46.

Cho, M., Kim, Y., and Ahn, J.H., 2007, Metamorphic Evolution of the Imjingang Belt, Korea: Implications for Permo-Triassic Collisional Orogeny: International Geology Review, v. 49, p. 3051.

Chopin, C. 1984, Coesite and pure pyrope in high-grade blueschists of the Western Alps: a first record and some consequences: Contributions to Mineralogy and Petrology, v. 86, p. 107-118.

Clinkscales, C., and Kapp, P., 2019, Structural style and kinematics of the Taihang-Luliangshan fold belt, North China: Implications for the Yanshanian orogeny: Lithosphere, v. 11, https://doi.org/10.1130/L1096.1.

Darby, B.J. and Ritts, B.D., 2007. Mesozoic structural architecture of the Lang Shan, North-central China: intraplate contraction, extension, and synorogenic sedimentation. Journal of Structural Geology 29, 2006-2007.

Davis, G.A., Zheng, Y.D., Wang, C., Darby, B.J., Zhang, C.H., and Gehrels, G., 2001, Mesozoic tectonic evolution of the Yanshan fold and thrust belt, with emphasis on Hebei and Liaoning provinces, northern China, in Hendrix, M.S., and Davis, G.A. eds., Paleozoic and Mesozoic tectonic evolution of Central and Asia: From Continental Assembly to Intracontinental Deformation: Geological Society of American Memoir 194, p. 171-194, https://doi.org/10.1130/0-8137-11940.171 .

Doglioni, C., 1987, Tectonics of the Dolomites (Southern Alps, Northern Italy): Journal of Structural Geology, v. 9, no. 2, p. 181-193.

Dong, S.W., et al., 2015, Late Jurassic-Early Cretaceous continental convergence and intracontinental orogenesis in East Asia: A synthesis of the Yanshan Revolution: Journal of Asian Earth Sciences, v. 114, p. 750-770.

Erscher, A., Masson, H., and Steck, A., 1993, Nappe geometry in the Western Swiss Alps: Journal of Structural Geology, v. 15, no. 3-5, p. 501-509.

Faure, M., Lin, W., and Sun, Y., 1998, Doming in the southern foreland of the Dabieshan (Yangtse block, China): Terra Nova, v. 10, no. 6, p. 307-311.

Faure, M., Lin, W., Shu, L.S., Sun, Y., and Schärer, U., 1999, Tectonics of the Dabieshan (eastern China) and possible exhumation mechanism of ultra high-pressure rocks: Terra Nova, v. 11, no. 6, p. 251-258.

Faure, M., Lin, W., and Le Breton, N., 2001, Where is the North China-South China block boundary in eastern China: Geology, v. 29, no. 2, p. 119-122. 
Faure, M., Lin, W., Monié, P., Le Breton, N., Poussineau, S., Panis, D., and Deloule, E., 2003a, Exhumation tectonics of the ultrahigh-pressure metamorphic rocks in the Qinling orogen in east China: New petrological-structural radiometric insights from the Shandong Peninsula: Tectonics, v. 22, no. 3, doi: 10.1029/2002TC001450.

Faure, M., Lin, W., Schärer, U., Shu, L.S., Sun, Y., and Arnaud, N., 2003b, Continental subduction and exhumation of UHP rocks. Structural and geochronological insights from the Dabieshan (East China): Lithos, v. 70, p. 213-241.

Faure, M., Lin, W., Monié, P., and Bruguier, O., 2004, Paleoproterozoic arc magmatism and collision in Liaodong Peninsula (north-east China): Terra Nova, v. 16, no. 2, p. 75-80.

Faure, M., Lin, W., and Chen, Y., 2012, Is the Jurassic (Yanshanian) intraplate tectonics of North

Ganne, J., Bertrand, J.M., and Fudral, S., 2005, Fold interference pattern at the top of basement domes and apparent vertical extrusion of HP rocks (Ambin and South Vanoise massifs, Western Alps): Journal of Structural Geology, v. 27, p. 553-570.

Guo, J.H., Chen, F.K., Zhang, X.M., Siebel, W., and Zhai, M.G., 2005, Evolution of syn- to postcollisional magmatism from north Sulu UHP belt, eastern China: zircon U-Pb geochronology [in Chinese with English abstract]: Acta Petrologica Sinica, v. 21, no. 4, p. 1281-1301.

Hacker, B.R., Wallis, S.R., McWilliams, M.O., and Gans, P.B., 2009, ${ }^{40} \mathrm{Ar} /{ }^{39} \mathrm{Ar}$ Constraints on the tectonic history and architecture of the ultrahigh-pressure Sulu orogen: Journal of Metamorphic Geology, v. 27, p. 827-844.

Hu, J.M., Zhao, Y., Liu, X.W., and Xu, G., 2010, Early Mesozoic deformations of the eastern Yanshan thrust belt, northern China: International Journal of Earth Science, v. 99, p. 785-800.

Huang, X.F., Shi, W., Chen, P., and Li, H.Q., 2015, Superposed deformation in the Helanshan Structural Belt: Implications for Mesozoic intracontinental deformation of the North China Plate: Journal of Asian Earth Sciences, v. 114, p. 140-154.

Higgins, A.K., and Leslie, A.G., 2000, Restoring thrusting in the East Greenland Caledonides: Geology, v. 28, no. 11, p. 1019-1022.

Ji, M., Liu, J.L., Hu, L., Guan, H.M., Davis, G.A., and Zhang, W., 2009, Zircon SHRIMP U-Pb age of Yinmawanshan and Zhaofang pluton in South Liaoning metamorphic core complex and its geological implications [in Chinese with English abstract]: Acta Petrologica Sinica, v. 25, no. 1, p. 173-181.

Li, S.G., et al., 1993, Collision of the North China and Yangtse Blocks and formation of coesite- 
bearing eclogites: Timing and processes: Chemical Geology, v. 109, p. 89-111.

Li, S.Z., Kusky, T.M., Liu, X.C., Zhang, G.W., Zhao, G.C., Wang, L., and Wang, Y.J., 2009a, Twostage collision-related extrusion of the western Dabie HP-UHP metamorphic terranes, central China: Evidence from quartz c-axis fabrics and structures: Gondwana Research, v. 16, p. 294-309.

Li, S.Z., Liu, X., Suo, Y.H., Liu, L.P., Qian, C.C., Liu, X.C., Zhang, G.W., and Zhao, G.C., 2009c, Triassic folding and thrusting in the Eastern block of the North China Craton and the Dabie-Sulu orogen and its geodynamics [in Chinese with English abstract]: Acta Petrologica Sinica, v. 25, no. 9, p. 2031-2049.

Li, S.Z., Kusky, T.M., Zhao, G.C., Liu, X.C., Zhang, G.W., Kopp, H., and Wang, L., 2010, Twostage Triassic exhumation of HP-UHP terranes in the western Dabie orogen of China: Constraints from structural geology: Tectonophysics, v. 490, p. 267-293.

Li, S.Z., et al., 2019, Mesozoic tectono-magmatic response in the East Asian ocean-continent connection zone to subduction of the Paleo-Pacific Plate: Earth-Science Reviews, v. 192, p. 91-137.

Li, X.H., Liu, Y., Li, Q.L., Guo, C.H., and Chamberlain, K.R., 2009b, Precise determination of Phanerozoic zircon $\mathrm{Pb} / \mathrm{Pb}$ age by multicollector SIMS without external standardization: Geochemistry Geophysics Geosystem, v. 10, Q04010, http://dx.doi.org/10.1029/2009GC002400.

Li, X.H., Tang, G.Q., Gong, B., Yang, Y.H., Hou, K.J., Hu, Z.C., Li, Q.L., Liu, Y., and Li, W.X., 2013, Qinghu zircon: a working reference for microbeam analysis of U-Pb age and Hf-O isotopes: Chinese Science Bulletin, v. 58, p. 4647-4654.

Li, Z., Chen, B., and Wei, C.J., 2017, Is the Paleoproterozoic Jiao-Liao-Ji Belt (North China Craton) a rift?: International Journal of Earth Science, v. 106, p. 355-375.

LBGMR (Liaoning Bureau of Geology and Mineral Resources), 1989, Regional geology of Liaoning Province [in Chinese with English summary]: Beijing, Geological Publishing House, p. 89-100.

Lin, W., Faure, M., Monié, P., Schärer, U., and Zhang, L., 2000, Tectonic of SE China, new insights from the Lushan massif (Jiangxi province): Tectonics, v. 19, p. 852-871.

Lin, W., Faure, M., Sun, Y., Shu, L.S., and Wang, Q.C., 2001, Compression to extension switch during the Middle Triassic orogeny of Eastern China: the case study of the Jiulingshan massif in the southern foreland of the Dabieshan: Journal of Asian Earth Sciences, v. 20, p. 31-43.

Lin, W., Faure, M., Wang, Q.C., Monié, P., and Panis, D., 2005a, Triassic polyphase deformation in the Feidong-Zhangbaling Massif (eastern China) and its place in the collision between the North China and South China blocks: Journal of Asian Earth Sciences, v. 25, p. 121-136. 
Lin, W., Faure, M., Wang, Q.C., and Arnaud, N., 2005b, Tectonic evolution of Dabie orogeny, in the view from polyphase deformation of Beihuaiyang metamorphic zone: Science in China (D), $v$. 35 , no. 2, p. 127-139.

Lin, W., Wang, Q. C., and Shi, Y. H., 2005c, Architecture, kinematics and deformation analysis in Dabie-Sulu collision zone [in Chinese with English abstract]: Acta Petrologica Sinica, v. 21, no. 4, p. 1195-1214.

Lin, W., Faure, M., Monié, P. and Wang, Q.C., 2007, Polyphase Mesozoic tectonics in the eastern part of the North China Block: Insights from the Eastern Liaoning Peninsula massif (NE China), in Zhai, M.G., Windley, B.F., Kusky, T.M., and Meng, Q.R., eds., Mesozoic Subcontinental Lithospheric Thinning Under Eastern Asia: Geological Society of London, Special Publications 280, p. $153-169$.

Lin, W., Faure, M., Monié, P., Schärer, U. and Panis, D., 2008, Mesozoic extensional tectonics in Eastern Asia: The South Liaodong Peninsula Metamorphic Core Complex (NE China): Journal of Geology, v. 116, p. 134-154.

Lin, W., Shi, Y. H., and Wang, Q. C., 2009, Exhumation tectonics of the HP-UHP orogenic belt in Eastern China: New structural-petrological insights from the Tongcheng massif, Eastern Dabieshan: Lithos, v. 109, p. 285-303.

Lin, W., Monié, P., Faure, M., Schärer, U., Shi, Y.H., Le Breton, N. and Wang, Q.C., 2011, Cooling paths of the NE China crust during the Mesozoic extensional tectonics: Example from the South Liaodong Peninsula metamorphic core complex: Journal of Asian Earth Sciences, v. 42, p. 1048 1065 .

Lin, W., Ji, W. B., Faure, M., Wu, L., Li, Q. L., Shi, Y. H., Schärer, U., Wang, F., and Wang, Q.C., 2015, Early Cretaceous extensional reworking of the Triassic HP-UHP metamorphic orogen in Eastern China: Tectonophysics, v. 662, p. 256-270.

Lin, W., and Wei, W., 2018, Late Mesozoic extensional tectonics in the North China Craton and its adjacent regions: a review and synthesis: International Geology Review, doi: 10.1080/00206814.2018.1477073.

Linzer, H.G., Ratschbacher, L., and Frisch, W., 1995, Transpressional collision structures in the upper crust: the fold-thrust belt of the Northern Calcareous Alps: Tectonophysics, v. 242, p. 41-61.

Liu, F.L., Gerdes, A., Liou, J.G., Xue, H.M., and Liang, F.H., 2006, SHRIMP U-Pb zircon dating from Sulu-Dabie dolomitic marble, eastern China: constraints on prograde, ultrahigh-pressure and retrograde metamorphic ages: Journal of Metamorphic Geology, v. 24, p. 569-589.

Liu, J.L., Davis, G.A., Lin, Z.Y., and Wu, F.Y., 2005, The Liaonan metamorphic core complex, southeastern Liaoning Province, North China: A likely contributor to Cretaceous rotation of eastern 
Liaoning, Korea and contiguous areas: Tectonophysics, v. 407, p. 65-80.

Liu, J.L., Ji, M., Shen, L., Guan, H.M., and Davis, G.A., 2011b, Early Cretaceous extension in the Liaodong Peninsula: Structural associations, geochronological constraints and regional tectonic implications: Science China Earth Science, v. 54, p. 823-842.

Liu, J.L., Shen, L., Ji, M., Guan, H.M., Zhang, Z.C., and Zhao, Z.D., 2013, The Liaonan/Wanfu metamorphic core complexes in the Liaodong Peninsula: Two stages of exhumation and constraints on the destruction of the North China Craton: Tectonics, v. 32, p. 1121-1141.

Liu, S.F., Gurnis, M., Ma, P.F., Zhang, B., 2017, Reconstruction of northeast Asian deformation integrated with western Pacific plate subduction since 200 Ma: Earth-Science Reviews, v. 175, p. 114-142.

Liu, W.C., Li, B.W., Pan, B.Y., and Liu, Y.B., 2001, Characteristics of deformation during Mesozoic era in the Chaohu-Chuzhou region, Anhui province [in Chinese with English abstract]: Geoscience, v. 15 , no. 13, p. 13-20.

Liu, X., Li, S.Z., Suo, Y.H., Liu, X.C., Dai, L.M., and Santosh, M., 2011a, Structural anatomy of the exhumation of high-pressure rocks: constraints from the Tongbai Collisional Orogen and surrounding units: Geological Journal, v. 46, p. 156-172.

Liu, X., Li, S.Z., Suo, Y.H., Liu, X.C., Dai, L.M., and Santosh, M., 2012, Structural analysis of the northern Tongbai Metamorphic Terranes, Central China: Implications for Paleozoic accretionary process on the southern margin of the North China Craton: Journal of Asian Earth Sciences, v. 47, p. $143-154$.

Ludwig, K.R., 2003, User's Manual for Isoplot 3.00: A Geochronological Toolkit for Microsoft Excel. Berkeley Geochronology Center Special Publication No. 4.

Luo, Y., S.M., Zhao, G.C., Li, S.Z., Xu, P., Ye, K., and Xia, X.P., 2004, LA-ICP-MS U-Pb zircon ages of the Liaohe Group in the Eastern Block of the North China Craton: constraints on the evolution of the Jiao-Liao-Ji Belt: Precambrian Research, v. 134, p. 349-371.

Mattauer, M., Matte, P., Malavieille, J., Tapponnier, P., Maluski, H., Xu, Z.Q., Lu, Y.L., and Tang, Y.Q., 1985, Tectonics of Qinling belt: build-up and evolution of eastern Asia: Nature, v. 317, p. 496-500.

Okay, A., Sengör, A., and Satir, M., 1993, Tectonics of an ultrahigh-pressure metamorphic terrane: the Dabie Shan/Tongbaishan orogen, China: Tectonics, v. 12, no. 6, p. 1320-1334.

Qiu, L., et al., 2018, The Zhayao tectonic window of the Jurassic Yuantai thrust system in Liaodong Peninsula, NE China: Geometry, kinematics and tectonic implications: Journal of Asian Earth Sciences, v. 164, p. 58-71. 
Ratschbacher, L., 1986, Kinematics of Austro-Alpine cover nappes: changing translation path due to transpression: Tectonophysics, v. 125, p. 335-356.

Ratschbacher, L., and Oertel, G., 1987, Superposed deformations in the Eastern Alps: strain analysis and microfabrics: Journal of Structural Geology, v. 9, p. 263-276.

Ratschbacher, L., Hacker, B.R., Calvert, A., Webb, L.E., Grimmer, J.C., McWilliams, M.O., Ireland, T., Dong, S.W., and Hu, J.M., 2003, Tectonics of the Qinling (Central China): tectonostratigraphy, geochronology, and deformation history: Tectonophysics, v. 366, p. 1-53.

Ren, Z.H., and Lin, W., 2019, Mesozoic tectonic evolution of eastern China: Insights from the Changshan Islands, NE China: Tectonophysics, v. 763, p. 46-60.

Schäfer, F., Oncken, O., Kemnitz, H., and Romer, R.L., 2000, Upper-plate deformation during collisional orogeny: a case study from the German Variscides (Saxo-Thuringian Zone), in Franke, W., Haak, V., Oncken, O., and Tanner, D., eds., Orogenic Processes: Quantification and Modelling in the Variscan Belt: Geological Society, London, Special Publications, v. 179, p. 281-302.

Schmid, J.C., Ratschbacher, L., Hacker, B.R., Gaitzsch, I., and Dong, S.W., 1999, How did the foreland react? Yangtze foreland fold-and-thrust belt deformation related to exhumation of the Dabie Shan ultrahigh-pressure crust (eastern China): Terra Nova, v. 11, no. 6, p. 266-272.

Shen, L., Liu, J.L., Hu, L., Ji, M., Guan, H.M., and Davis, G.A., 2011, The Dayingzi detachment fault system in Liaodong Peninsula and its regional tectonic significance: Science China Earth Science, v. 41, p. 437- 451.

Sláma, J., et al., 2008, Plešovice zircon-a new natural reference material for U/Pb and Hf isotopic microanalysis: Chemical Geology, v. 249, p. 1-35.

Sun, X.M., Zhang, M.S., Long, S.X., Hao, F.J., Liu, P.J., and Liu, C.Y., 2004, Overthrust tectonic in northern Qinling-Dabie orogenic belt and basin-controlling faults in Zhoukou depression and Hefei basin [in Chinese with English abstract]: Oil \& Gas Geology, v. 25, no. 2, p. 191-198.

Wan, Y.S., Dong, C.Y., Liu, D.Y., Kröner, A., Yang, C.H., Wang, W., Du, L.L., Xie, H.Q., and Ma, M.Z., 2012, Zircon ages and geochemistry of late Neoarchean syenogranites in the North China Craton: A review: Precambrian Research, v. 222-223, p. 265-289.

Wang, E.C., Meng, Q.R., Burchfiel, B.C., and Zhang, G.W., 2003, Mesozoic large-scale lateral extrusion, rotation, and uplift of the Tongbai-Dabie Shan belt in east China: Geology, v. 31, no. 4, p. 307-310.

Wang, L., Kusky, T.M., and Li, S.Z., 2010, Structural geometry of an exhumed UHP terrane in the eastern Sulu Orogen, China: Implications for continental collisional processes: Journal of Structural 
Geology, v. 32, p. 423-444.

Wang, P.P., Song, C.Z., Li, J.H., Ren, S.L., Zhang, Y., and Wang, W., 2016, Tectonic characteristics and geochronology of Mashan nappe structure in Bengbu [in Chinese with English abstract]: Journal of Hefei University of Technology, v. 39, no. 3, p. 385-394.

Wang, T., Zheng, Y.D., Zhang, J.J., Zeng, L.S., Donskaya, T., Guo, L., and Li, J.B., 2011a, Pattern and kinematic polarity of late Mesozoic extension in continental NE Asia: Perspectives from metamorphic core complexes: Tectonics, v. 30, TC6007, doi:10.1029/2011TC002896.

Wang, T., Guo, L., Zheng, Y.D., Donskaya, T., Gladkochub, D., Zeng, L.S., Li, J.B., Wang, Y.B., and Mazukabzov, A., 2012, Timing and processes of late Mesozoic mid-lower-crustal extension in continental NE Asia and implications for the tectonic setting of the destruction of the North China Craton: Mainly constrained by zircon U-Pb ages from metamorphic core complexes: Lithos, v. 154, p. 315-345.

Wang, X.D., Neubauer, F., Genser, J., and Yang, W.R., 1998, The Dabie UHP unit, Central China: a Cretaceous extensional allochthon superposed on a Triassic orogen: Terra Nova, v. 10, no. 5, p. 260-267.

Wang, Y., and Li, H.M., 2008, Initial Formation and Exhumation of an Intracontinental Tectonic Belt-An Example from the Northern Part of the Taihang Mountain Belt, Eastern Asia: Journal of Geology, v. 116, p. 155-172.

Wang, Y., Zhou, L.Y., and Li, J.Y., 2011b, Intracontinental superimposed tectonics - A case study in the Western Hills of Beijing, eastern China: Geological Society of America Bulletin, v. 123, no. 5/6, p. 1033-1055.

Wang, Y., Zhou, L.Y., Zhao, L.J., Cope, T., and Liu, J., 2015, Tectonic transformations in the north of eastern China during 170-150 Ma: Causal linkage to the rapid formation of the paleo-Pacific plate, in Anderson, T.H., Didenko, A.N., Johnson, C.L., Khanchuk, A.L., and MacDonald, J.H., Jr., eds., Late Jurassic Margin of Laurasia-A Record of Faulting Accommodating Plate Rotation: Geological Society of America Special Paper 513, p. 561-587.

Wang, Y., Zhou, L.Y., and Luo, Z.H., 2017b, Kinematics and timing of continental block deformation from margins to interiors: Terra Nova, v. 29, p. 253-263.

Wang, Y., Sun, L.X., Zhou, L.Y., and Xie, Y.T., 2018, Discussion on the relationship between the Yanshanian Movement and cratonic destruction in North China: Science China Earth Sciences, v. 61, p. 499-514.

Wang, Y.C., Dong, S.W., Shi, W., Chen, X.H. and Jia, L.M., 2017a, The Jurassic structural evolution of the western Daqingshan area, eastern Yinshan belt, North China: International Geology Review, v. 59, no. 15, p. 1885-1907. 
Wang, Z.X., Tang, Z.M., Yang, Z.Z., and Yang, X.B., 2000a, Ductile tectonic deformation of Mesozoic time in the Dalian area [in Chinese with English abstract]: Seismology and Geology, v. 22 , no. 4, p. 379-386.

984

985

986

987

988

989

990

991

992

993

994

995

996

997

998

999

1000

1001

1002

1003

1004

1005

1006

1007

1008

1009

1010

1011

1012

1013

1014

1015

1016

1017

1018

1019

1020

1021

1022

1023

Wang, Z.X., Tang, Z.M., Yang, Z.Z., and Yang, X.B., 2000b, Redetermination of the MesoCenozoic structural framework of Dalian area [in Chinese with English abstract]: Regional Geology of China, v. 19, no. 2, p. 120-126.

Wang, Z.X., Yang, T.N., and Tang, Z.M., 2001, The NS-trending shear traction deformation in Dalian area, Northeast China [in Chinese with English abstract]: Acta Petrologica et Mineralogica, v. 20 , no. 2 , p. 208-216.

Wang, Z.X., Yang, T.N., Peng, Y., Tang, Z.M., Yang, X.B., Yang, Z.Z., Gao, L.Z. and Li, D.Z. 2002, The People's Republic of China, Lushun-Dalian area, 1: 50,000 Geological Survey Report [in Chinese], p. 100-104.

Willett, S., Beaumont, C., and Fullsack, P., 1993, Mechanical model for the tectonics of doubly vergent compressional orogens: Geology, v. 21, p. 371-374.

Wu, F.Y., Yang, J.H., and Liu, X.M., 2005a, Geochronological framework of the Mesozoic granitic magmatism in the Liaodong Peninsula, Northeast China [in Chinese with English abstract]: Geological Journal of China Universities, v. 11, no. 3, p. 305-317.

Wu, F.Y.; Yang, J.H.; Wilde, S. A.; and Zhang, X. 2005b, Geochronology, petrogenesis and tectonic implications of the Jurassic granites in the Liaodong Peninsula, NE China: Chemical Geology, v. 221, p. 127-156.

Wu, F.Y., Lin, J.Q., Wilde, S. A., Zhang, X.O., and Yang, J.H., 2005c, Nature and significance of the Early Cretaceous giant igneous event in eastern China: Earth and Planetary Science Letters, v. 233, p. 103-119.

Xia, Z.M., Liu, J. L., Ni, J.L., Zhang, T.T., Shi, X.M., and Wu, Y., 2016, Structure, evolution and regional tectonic implications of the Queshan metamorphic core complex in eastern Jiaodong Peninsula of China: Science China Earth Science, v. 46, p. 356-373.

Xu, Z.Q., Li, H.B., Wang, Z.X., and Li, D.Z., 1991, A contraction to extension in the crust of south Liaoning Peninsula [in Chinese with English abstract]: Geological Review, v. 37, no. 3, p. 193-202.

Xu, Z.Q., Zeng, L.S., Liu, F.L., Yang, J.S., Zhang, Z.M., McWilliams, M., and Liou, J.G., 2006, Polyphase subduction and exhumation of the Sulu high-pressure-ultrahigh-pressure metamorphic terrane, in Hacker, B.R., McClelland, W.C., and Liou, J.G., eds., Ultrahigh-pressure metamorphism: Deep continental subduction: Geological Society of America, Special Paper 403, p. 93-114. 
Xue, F., Rowley, D.B., and Baker, J., 1996, Refolded syn-ultrahigh-pressure thrust sheets in the south Dabie complex, China: Field evidence and tectonic implications: Geology, v. 24, no. 5, p. 455-458.

Yang, D.B., Xu, W.L., Xu, Y.G., Wang, Q.H., Pei, F.P., and Wang, F., 2012, U-Pb ages and Hf isotope data from detrital zircons in the Neoproterozoic sandstones of northern Jiangsu and southern Liaoning Provinces, China: Implications for the Late Precambrian evolution of the southeastern North China Craton: Precambrian Research, v. 216-219, p. 162-176.

Yang, G., Chai, Y.C., and Wu, Z.W., 2001, Thin-skinned thrust nappe structures in western Liaoning in the eastern sector of the Yanshan orogenic belt [in Chinese with English abstract]: Acta Geologica Sinica, v. 75, no. 3, p. 322-332.

Yang, J.H., Chung, S.L., Wilde, S.A., Wu, F.Y., Chu, M.F., Lo, C.H., and Fan, H.R., 2005, Petrogenesis of post-orogenic syenites in the Sulu Orogenic Belt, East China: geochronological, geochemical and Nd-Sr isotopic evidence: Chemical Geology, v. 214, p. 99-125.

Yang, J.H., Wu, F.Y., Chung, S.L., Lo, C.H., Wilde, S.A. and Davis, G.A., 2007a, Rapid exhumation and cooling of the Liaonan metamorphic core complex: Inferences from ${ }^{40} \mathrm{Ar} /{ }^{39} \mathrm{Ar}$ thermochronology and implications for Late Mesozoic extension in the eastern North China Craton: Geological Society of America Bulletin, v. 119, no. 11/12, p. 1405-1414.

Yang, J.H., Wu, F.Y., Liu, X.M., Xie, L.W., and Yang, Y.H., 2007b, Petrogenesis and geological significance of the Jurassic Xiaoheishan pluton in the Liaodong Peninsula, East China: In-situ Zircon U-Pb dating and $\mathrm{Hf}$ isotopic analysis [in Chinese with English abstract]: Bulletin of Mineralogy, Petrology and Geochemisty, v. 26, no. 1, p. 29-43.

Yang, T.N., Peng, Y., Wang, Z.X., Li, D.Z., Yang, Z.Z., and Wang, G.Z., 2002, Nearly N-S compressional deformation of sedimentary cover in the Lushun-Dalian area: Intraplate deformation effect of overlying plate on continental deep-subduction of the Sulu area [in Chinese with English abstract]: Geological Bulletin of China, v. 21, no. 6, p. 308-314.

Yang, T.N., Peng, Y., Leech, M.L., and Lin, H.Y., 2011, Fold patterns indicating Triassic constrictional deformation on the Liaodong peninsula, eastern China, and tectonic implications: Journal of Asian Earth Sciences, v. 40, p. 72-83.

Ye, K., Cong, B.L., and Ye, D.N., 2000, The possible subduction of continental material to depths greater than $200 \mathrm{Km}$ : Nature, v. 407, p. 734-736.

Yin, A., and Nie, S.Y., 1993, An indentation model for the North and South China collision and the development of the Tan-Lu and normal fault systems, eastern Asia: Tectonics, v. 12, no. 4, p. 801 813.

Yin, A., and Nie, S.Y., 1996, Phanerozoic palinspastic reconstruction of China and its neighboring 
regions, in Yin, A., and Harrison, T. A., eds., The tectonic evolution of Asia: New York, Cambridge University Press, p. 442-485.

Zhang, S.H., Zhao, Y., Ye, H., and Hu, G.H., 2016, Early Neoproterozoic emplacement of the diabase sill swarms in the Liaodong Peninsula and pre-magmatic uplift of the southeastern North China Craton: Precambrian Research, v. 272, p. 203-225.

Zhang, Y.Q., Dong, S.W., Zhao, Y., and Zhang, T., 2007, Jurassic Tectonics of North China: a synthetic view [in Chinese with English abstract]: Acta Geologica Sinica, v. 81, no. 11, p. 14621480 .

Zhou, J.B., Cao, J.L., Wilde, S.A., Zhao, G.C., Zhang, J.J., and Wang, B., 2014, Paleo-Pacific subduction-accretion: Evidence from Geochemical and $\mathrm{U}-\mathrm{Pb}$ zircon dating of the Nadanhada accretionary complex, NE China: Tectonics, v. 33, p. 2444-2466.

Zhu, G., 1993, Geotectonic implications of the deformation and metamorphism of the Penglai Group of the Jiaobei region, China [in Chinese with English abstract]: Geotectonica et Metallogenia, v. 17, no. 3, p. 259-270.

Zhu, G., Evans, J.A., Fitches, W.R., Fletcher, C.J.N., Rundle, C.R., and Xu, J.W., 1994, Isotopic constraints on the Paleozoic evolution of the Shandong Peninsula, N.E. China: Journal of Southeast Asian Earth Sciences, v. 9, p. 241-248.

Zhu, G., and Xu, J.W., 1994, Deformation and metamorphic evolution in the Jiaobei region, eastern Shandong [in Chinese with English abstract]: Journal of Hefei University of Technology, v. 17, no. 3, p. 148-162.

Zhu, G., Wang, Y.S., Wang, W., Zhang, S., Liu, C., Gu, C.C., and Li, Y.J., 2017, An accreted microcontinent in the north of the Dabie Orogen, East China: Evidence from detrital zircon dating: Tectonophysics, v. 698, p. 47-64.

Zhu, R.X., Yang, J.H., and Wu, F.Y., 2012, Timing of destruction of the North China Craton: Lithos, v. 149 , p. $51-60$.

Zhu, R.X. and Xu, Y.G., 2019, The subduction of the west Pacific plate and the destruction of the North China Craton. Science China Earth Sciences, v. 62, p. 1340-1350. 


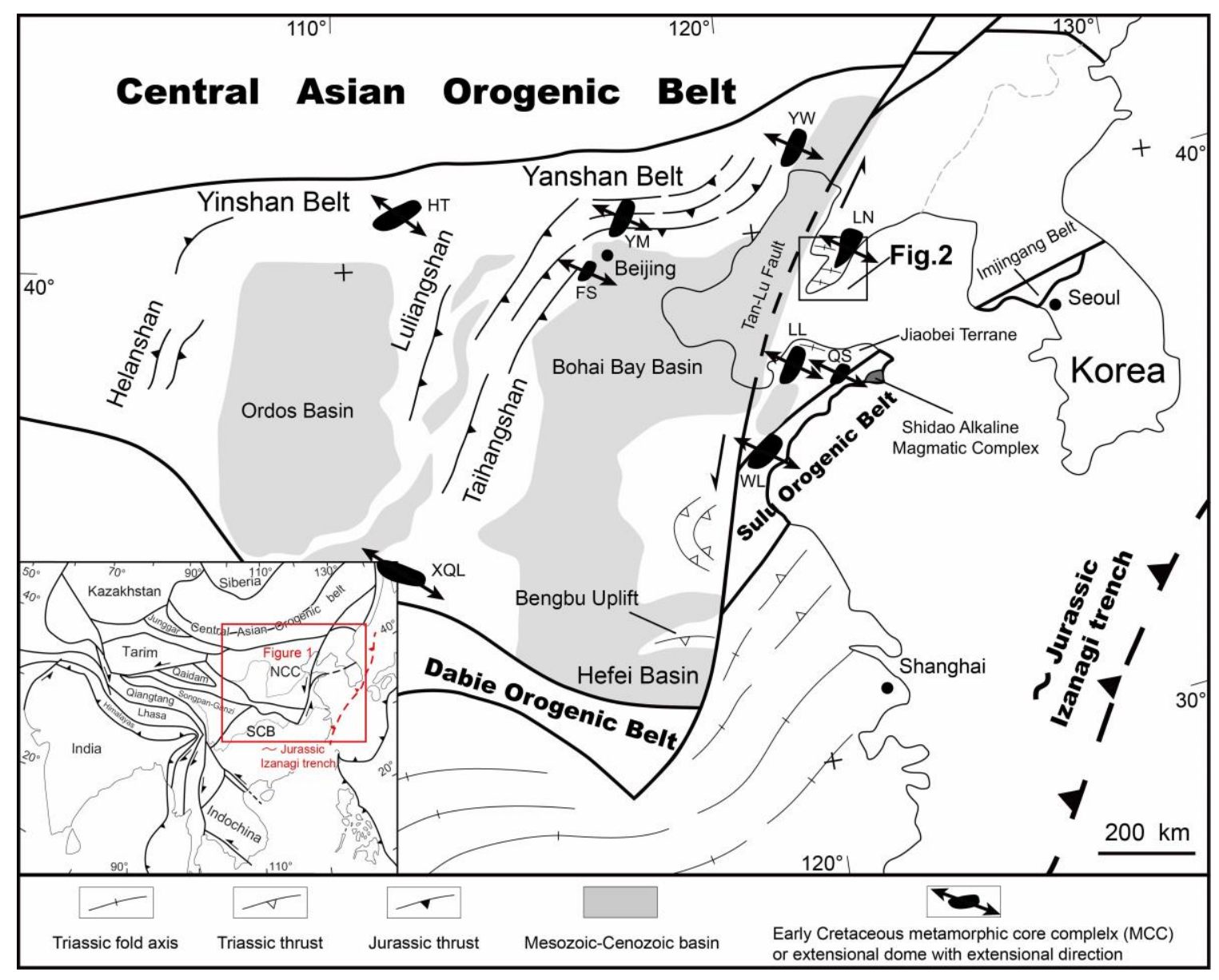

Fig. 1. Simplified tectonic framework of the NCC and the location of the South Liaodong Peninsula (modified from Cho et al., 2007; Wang et al., 2011b; Clinkscales and Kapp, 2019; Lin and Wei, 2018). NCC: North China Craton; SCB: South China Block; FS: Fangshan antiform; HT: Hohhot MCC; LL: Linglong dome; LN: Liaonan MCC; QS: Queshan MCC; WL: Wulian MCC; XQL: Xiaoqinling MCC; YM: Yunmengshan syntectonic pluton reworked by a ductile normal fault; YW: 
Yiwulushan pluton reworked by a ductile normal fault 


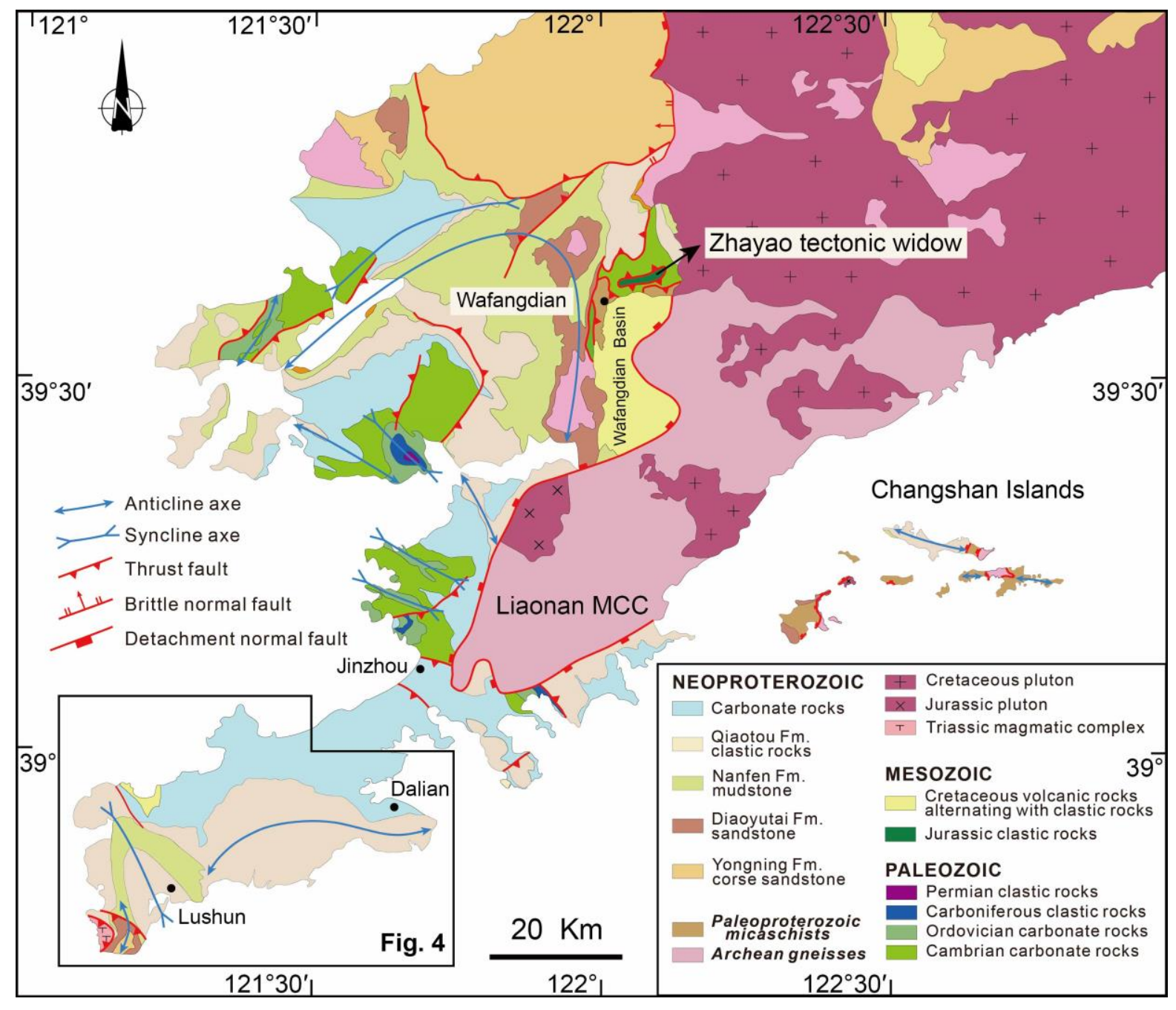

Fig. 2. Simplified geological map of the South Liaodong Peninsula. 


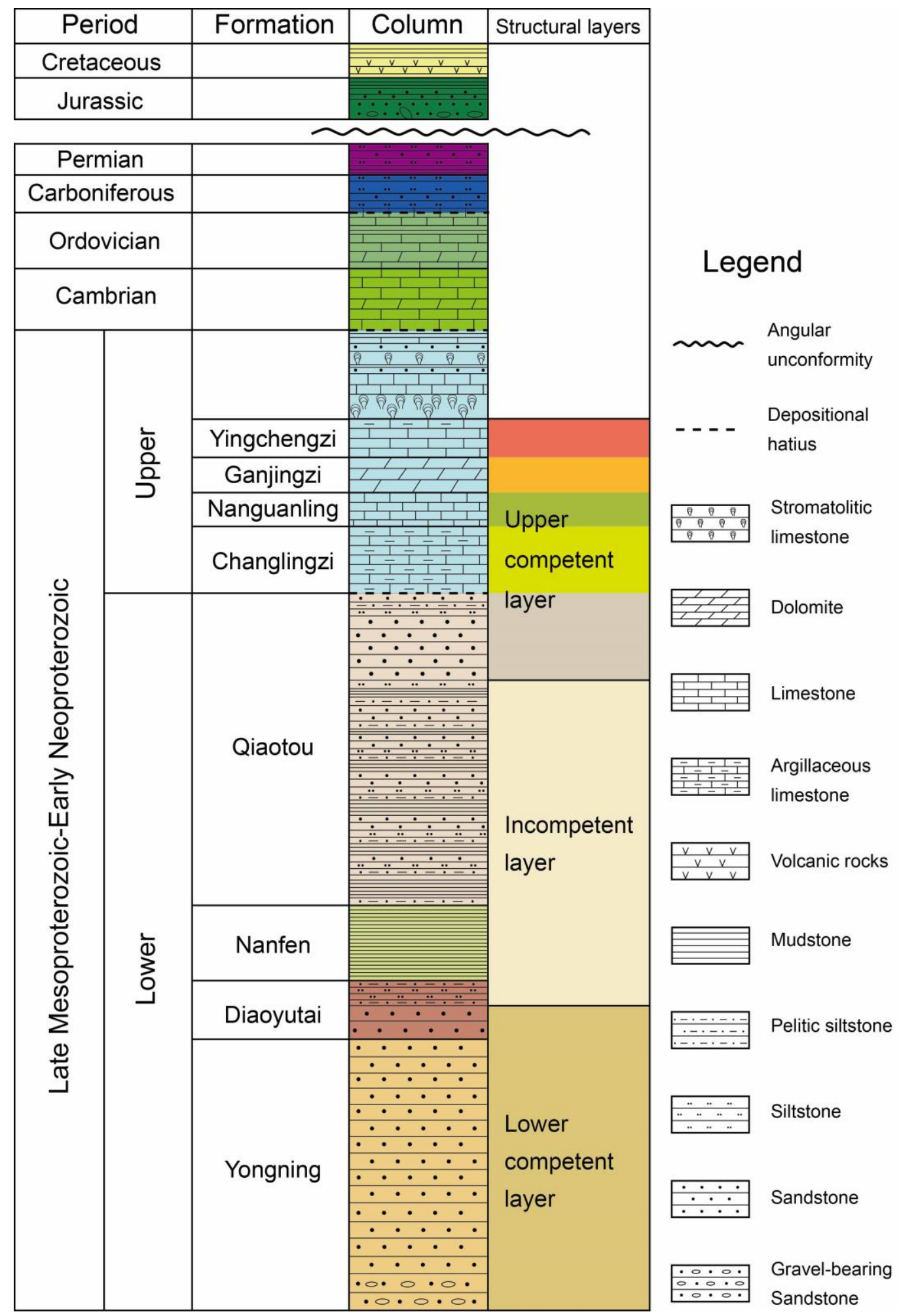

Fig. 3. The sedimentary sequence of the South Liaodong Peninsula (modified from Yang et al., 2011), and the structural layers of the Lushun-Dalian area. 


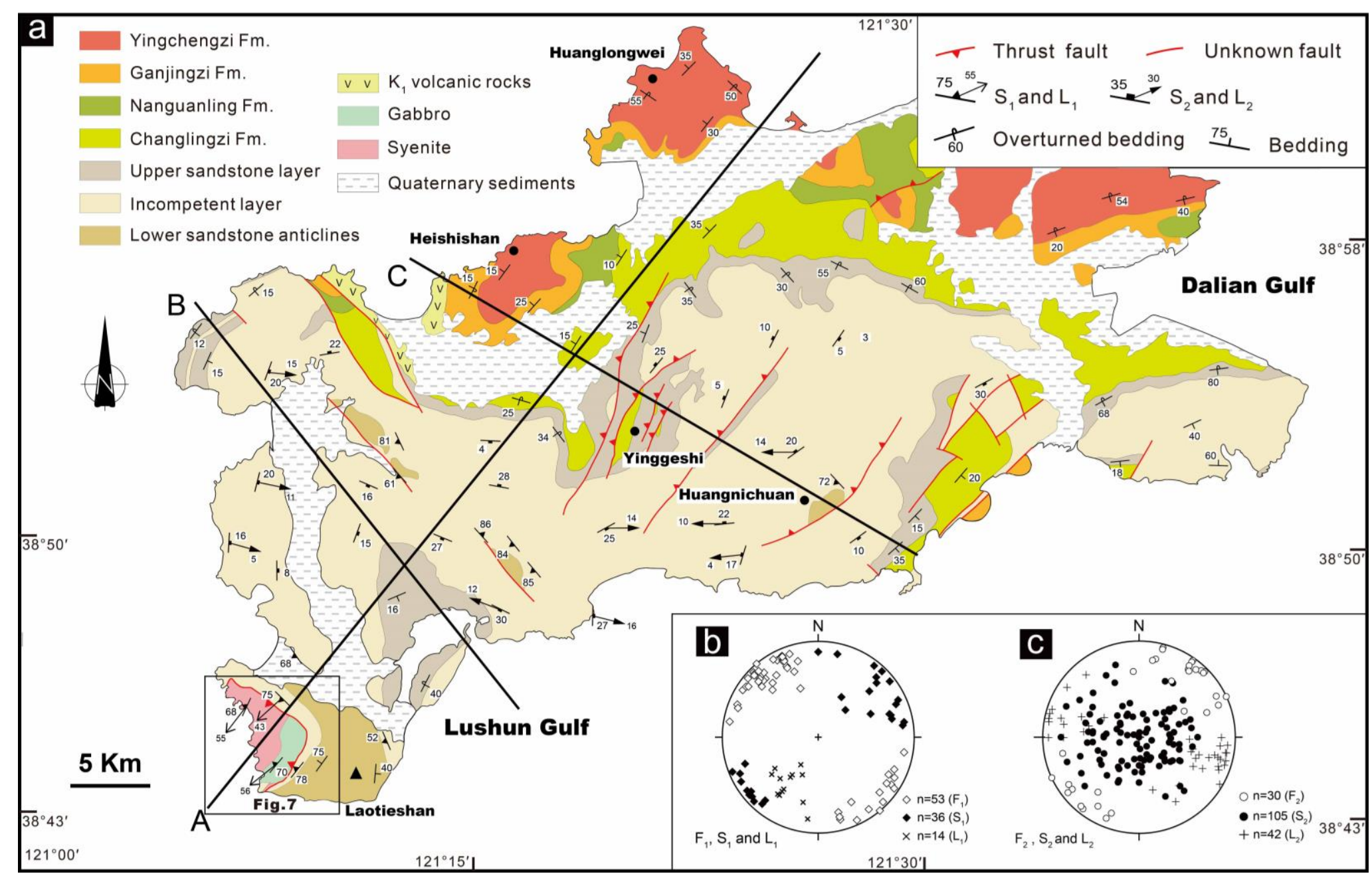

Fig. 4. a, Structural geological map of the Lushun-Dalian area. Equiareal stereograms (Schmidt net, lower hemisphere) of the structural elements. b, Fold axes $F_{1}$ and $\mathrm{S}_{1}$ foliation. c, Fold axes $\mathrm{F}_{2}, \mathrm{~S}_{2}$ foliation and $\mathrm{L}_{2}$ lineation. 


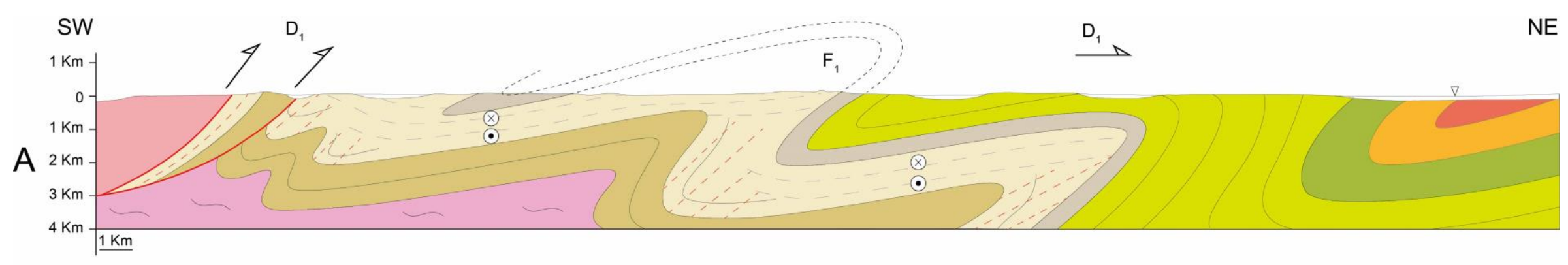

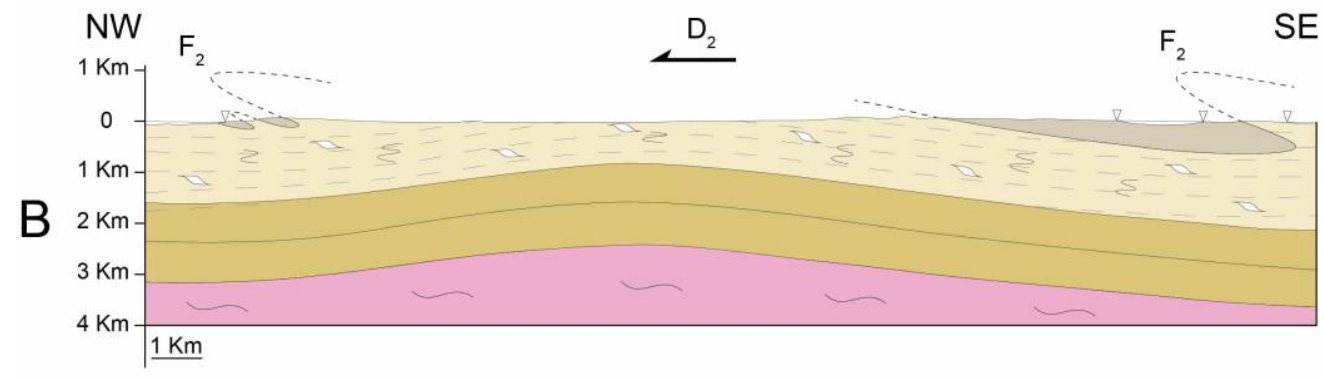

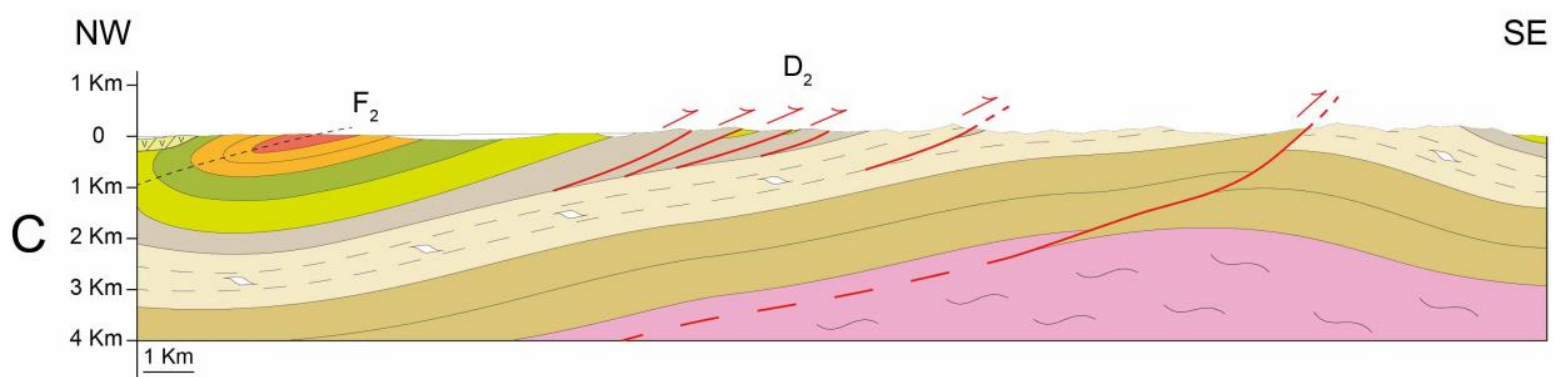

\section{$\nabla \quad$ Sea level \\ $-\stackrel{\otimes}{-}-D_{2}$ Kinematics}

SE Folded bedding with $\mathrm{S}_{1}$ cleavages

$\mathrm{S}_{2-}^{-} \S_{-}^{-} \quad$ Intrafolial folds with $\mathrm{S}_{2}$ cleavages

Archean gneisses and Paleoproterozoic micaschists

Fig. 5. Cross sections through the Lushun-Dalian area (locations in Fig. 3) drawn parallel to the direction of the main mineral and stretching lineation. A, Section along $\mathrm{D}_{1}$ lineation; $\mathbf{B}$ and $\mathbf{C}$, Sections along $\mathrm{D}_{2}$ lineation 


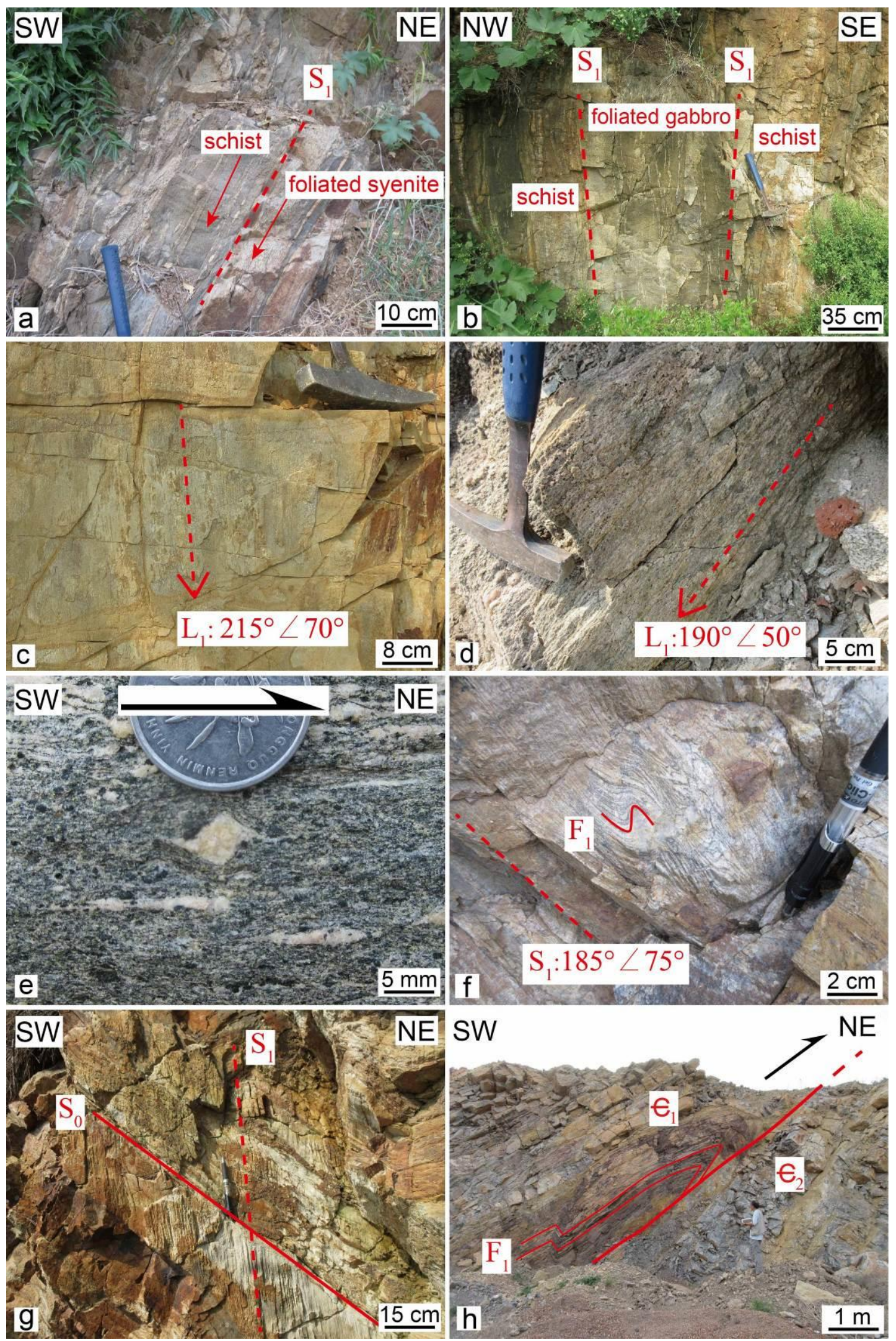

Fig. 6. Field photographs of structures associated with the $D_{1}$ deformation. a, Syenite intrusion and country rocks concurrently foliated $\left(38^{\circ} 45^{\prime} 56.63^{\prime \prime}, 121^{\circ} 8^{\prime} 43.91^{\prime \prime}\right)$. b, Gabbro intrusion and country rocks concurrently deformed $\left(38^{\circ} 44^{\prime} 16.88^{\prime \prime}, 121^{\circ} 9^{\prime} 7.52^{\prime \prime}\right)$. c, Stretching $\mathrm{L}_{1}$ lineation exhibited on the $\mathrm{S}_{1}$ foliation in slate $\left(38^{\circ} 45^{\prime} 38.16^{\prime \prime}, 121^{\circ} 9^{\prime} 15.48^{\prime \prime}\right)$. d, Stretching $\mathrm{L}_{1}$ lineation 
exhibited on the $S_{1}$ foliation of the mylonitized syenite ( $\left.38^{\circ} 44^{\prime} 7.14^{\prime \prime}, 121^{\circ} 8^{\prime} 8.18^{\prime \prime}\right)$. e, Delta-type $\mathrm{K}$-feldspar porphyroclast in the mylonitized syenite indicating a top-to-the-NE shear sense (38 $\left.45^{\prime} 19.5^{\prime \prime}, 121^{\circ} 7^{\prime} 40.09 "\right)$. f, Penetrative SW-dipping $S_{1}$ and small intrafolial folds in the slate of the country rocks of the Yinjiacun complex (38 $\left.46^{\prime} 3^{\prime \prime}, 121^{\circ} 8^{\prime} 8.77^{\prime \prime}\right)$. g, Subvertical $S_{1}$ in the siltstone of Diaoyutai Formation, east of Lushun city (38 $\left.49^{\prime} 51.06^{\prime \prime}, 121^{\circ} 16^{\prime} 47.94 "\right)$. h, Fold and thrust in the limestone, north of Jinzhou city (39 $\left.15^{\prime} 59.76^{\prime \prime}, 121^{\circ} 37^{\prime} 12.36 "\right)$.
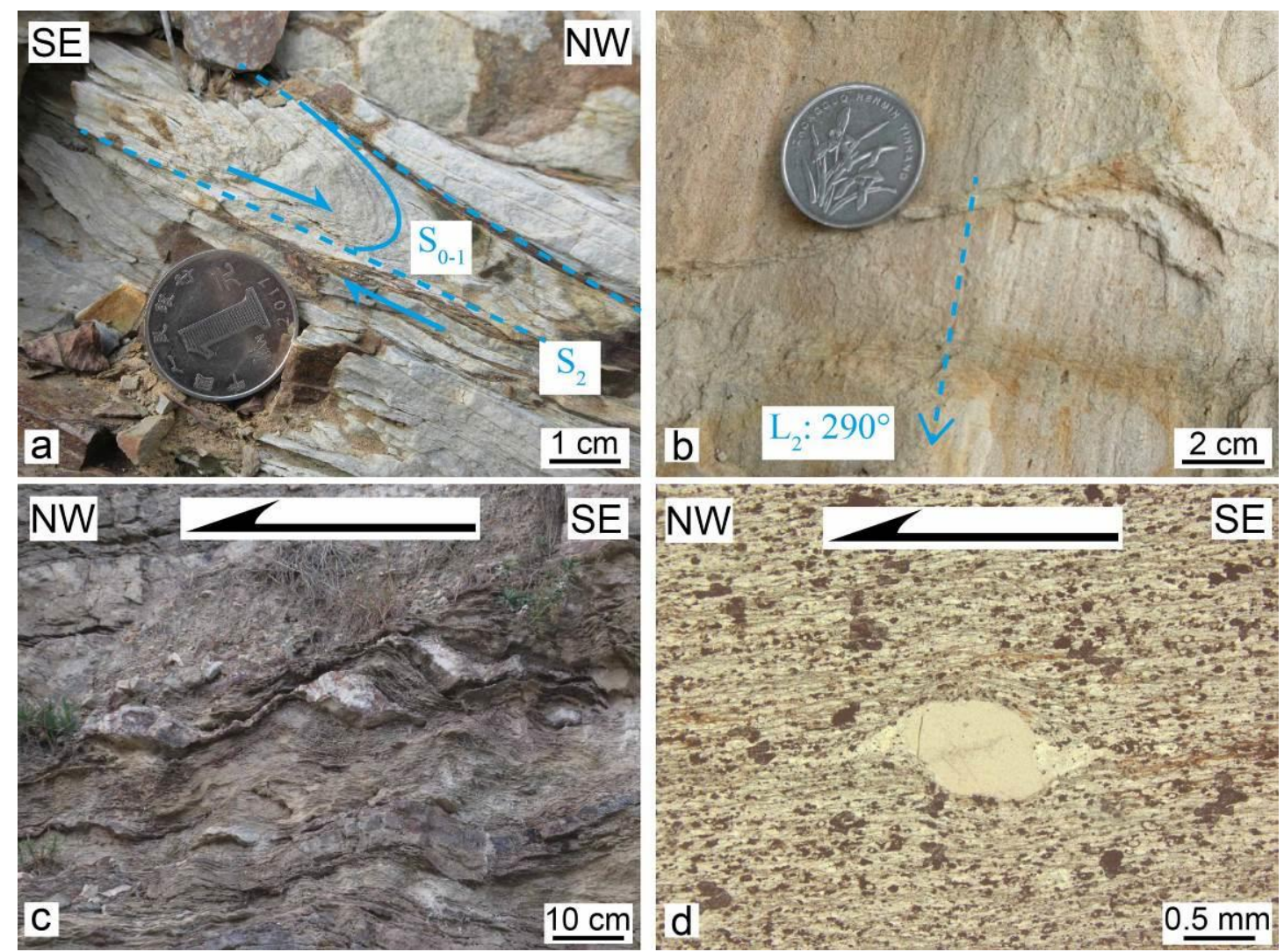

Fig. 7. Field photographs and microphotographs of structures associated with the $\mathrm{D}_{2}$ deformation. a, Intrafolial $F_{2}$ fold preserved in slate of the Qiaotou formation (38 $\left.55^{\prime} 16.23 ", 121^{\circ} 9^{\prime} 9.49^{\prime \prime}\right)$. b, NW-SE trending mineral stretching $\mathrm{L}_{2}$ lineation developed in the $\mathrm{S}_{2}$ foliation of the Diaoyutai formation ( $\left.38^{\circ} 48^{\prime} 24.97^{\prime \prime}, 121^{\circ} 17^{\prime} 27.72^{\prime \prime}\right)$. c, Sigmoidal quartz boudins in the Qiaotou formation indicating a top-to-the-NW shearing (38 47'29.41", 121 $\left.16^{\circ} 40.75^{\prime \prime}\right)$. d, Sigma-type quartz porphyroclast in the slate of the Diaoyutai formation indicating a top-to-the-NW shearing (38 $\left.48^{\prime} 43.63^{\prime \prime}, 121^{\circ} 17^{\prime} 24.82^{\prime \prime}\right)$. 


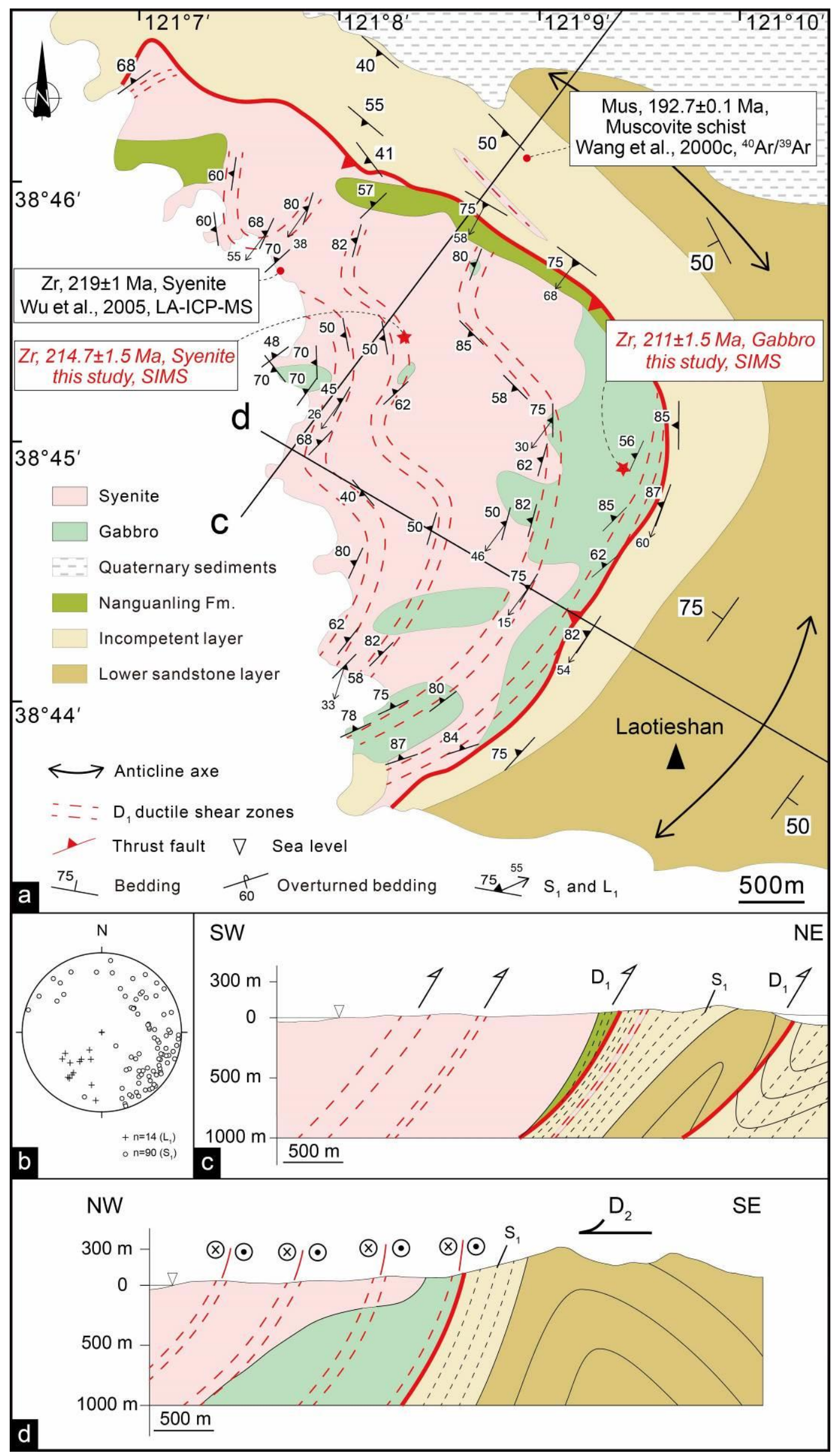


Fig. 8. a, Detailed structural map of the Yinjiacun magmatic complex. b, Equiareal stereogram (Schmidt net, lower hemisphere) of the $S_{1}$ foliation and $L_{1}$ lineation in the Yinjiacun complex and its country rocks. $\mathbf{c}$ and $\mathbf{d}$, NE-SW and NW-SE cross-sections of the Yinjiacun complex and its country rocks, respectively. 


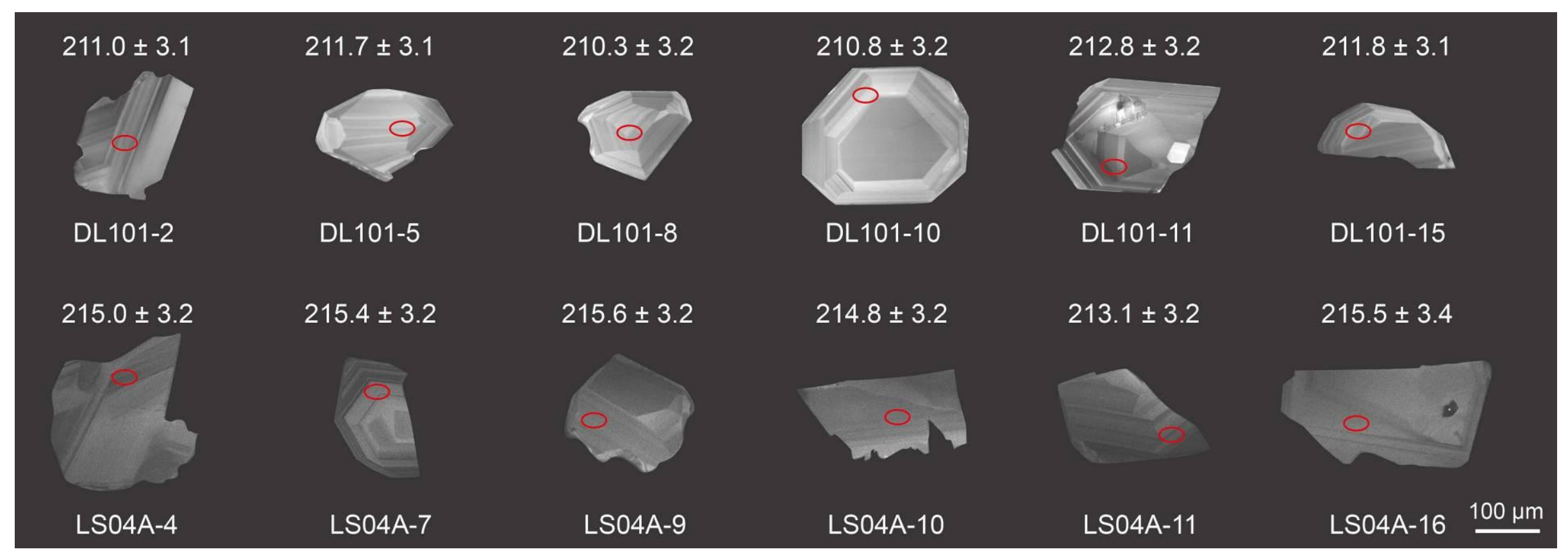

Fig. 9. Cathodoluminescence images of representative zircons from the gabbro and syenite samples. Red ellipses indicate the analytical spots with measured ages. 

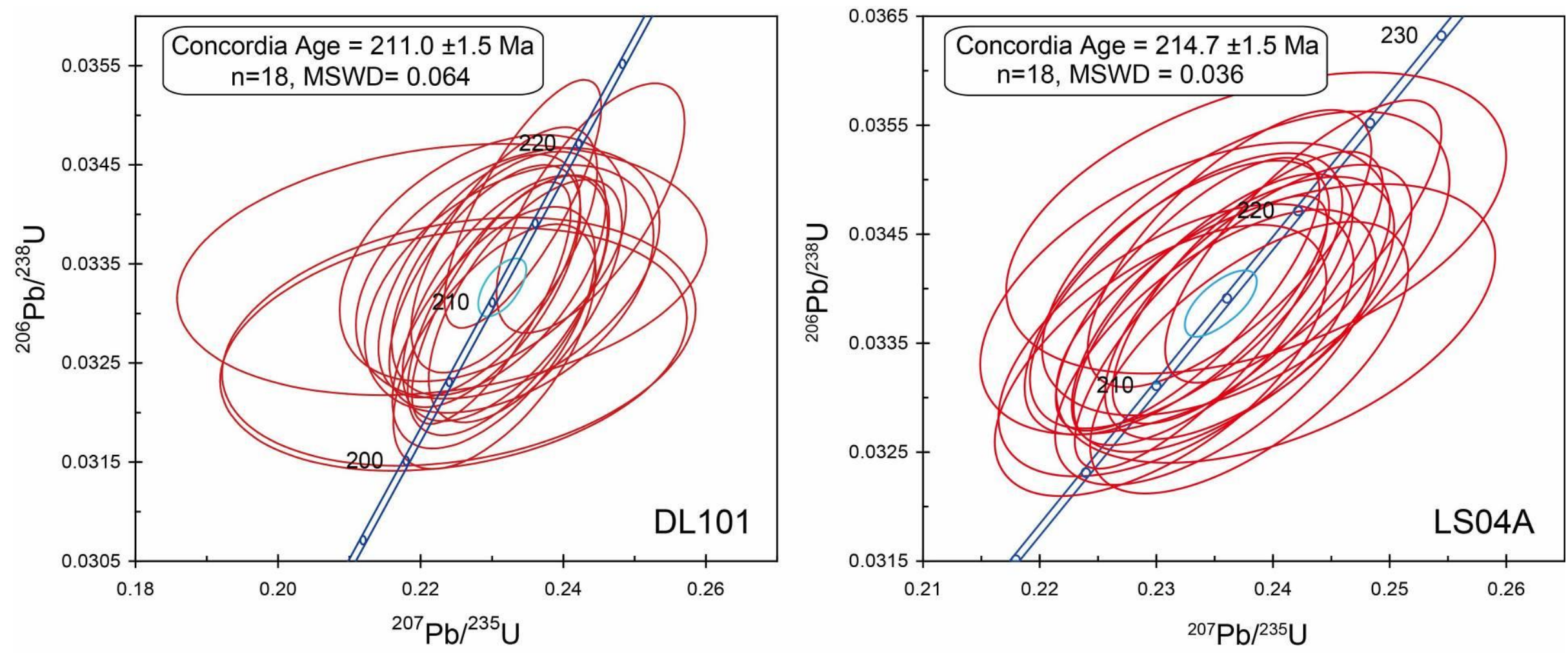

Fig. 10. SIMS U-Pb concordia diagram of the analyzed zircons, sample locations are shown in Fig. 7a. 


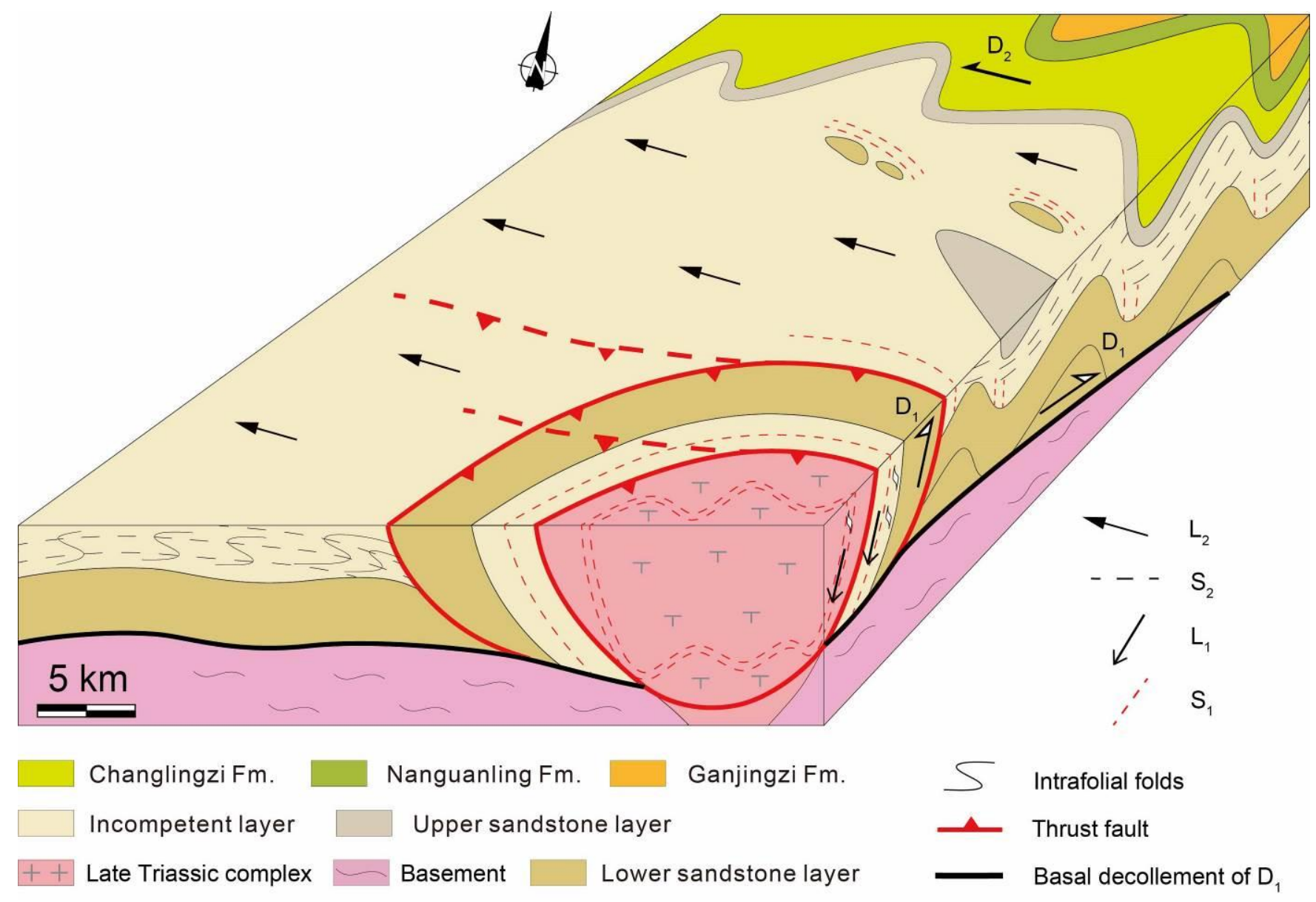

Fig. 11. Schematic block diagram showing the $\mathrm{D}_{1}$ and $\mathrm{D}_{2}$ deformation of the Lushun-Dalian area, South Liaodong Peninsula. 


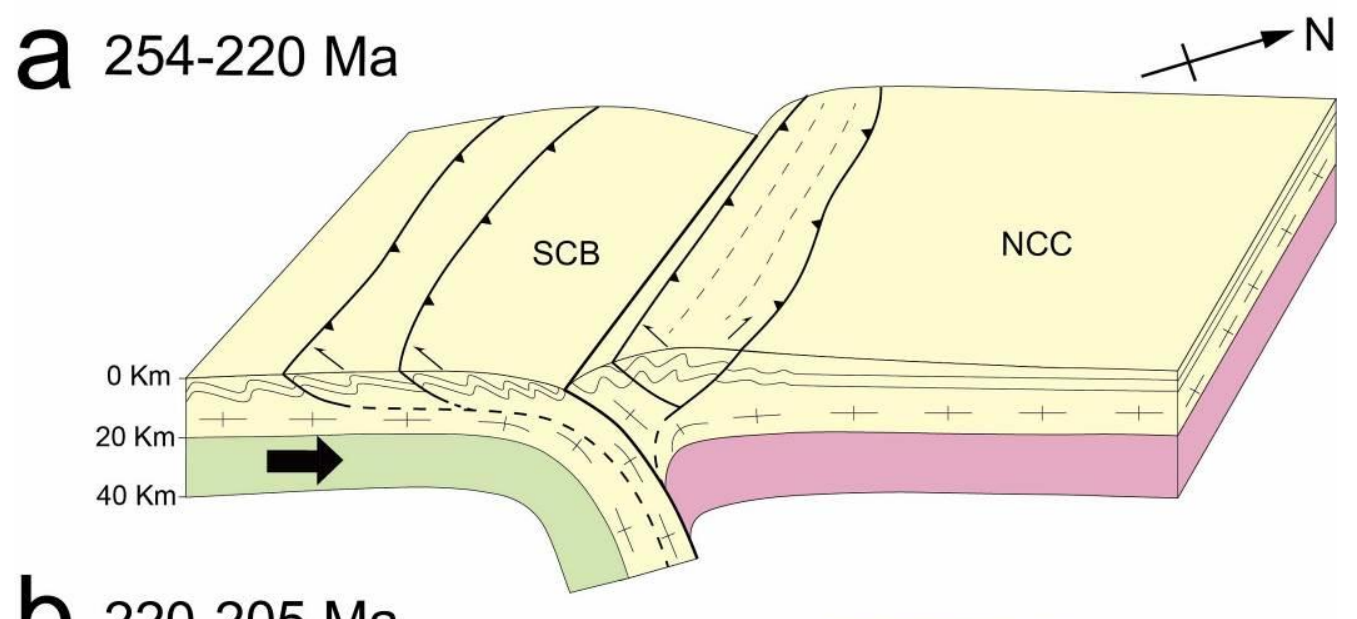

b $220-205 \mathrm{Ma}$

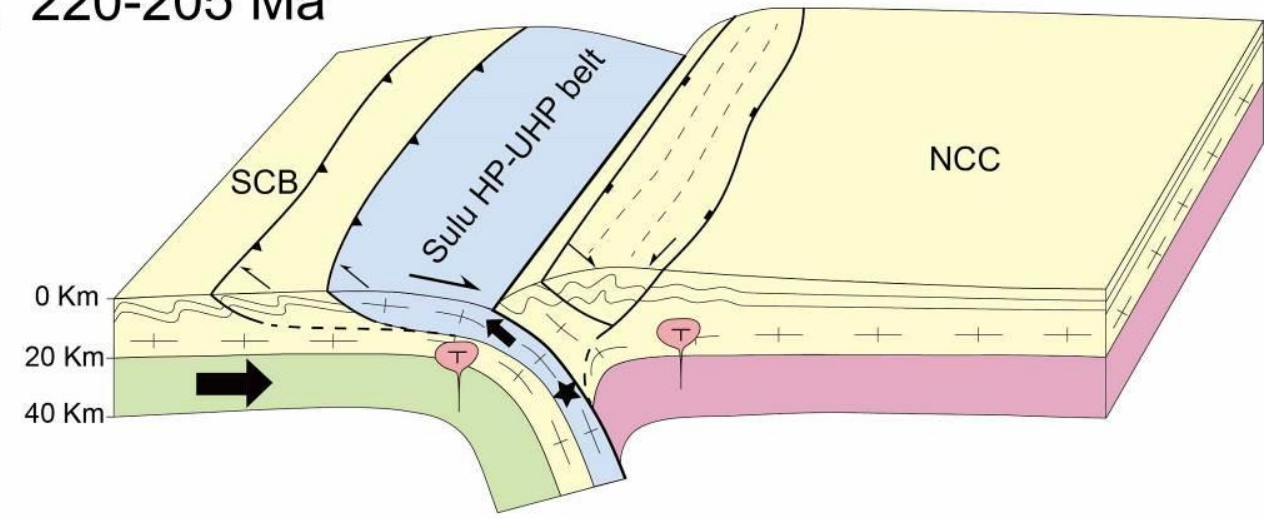

C 205-170 Ma

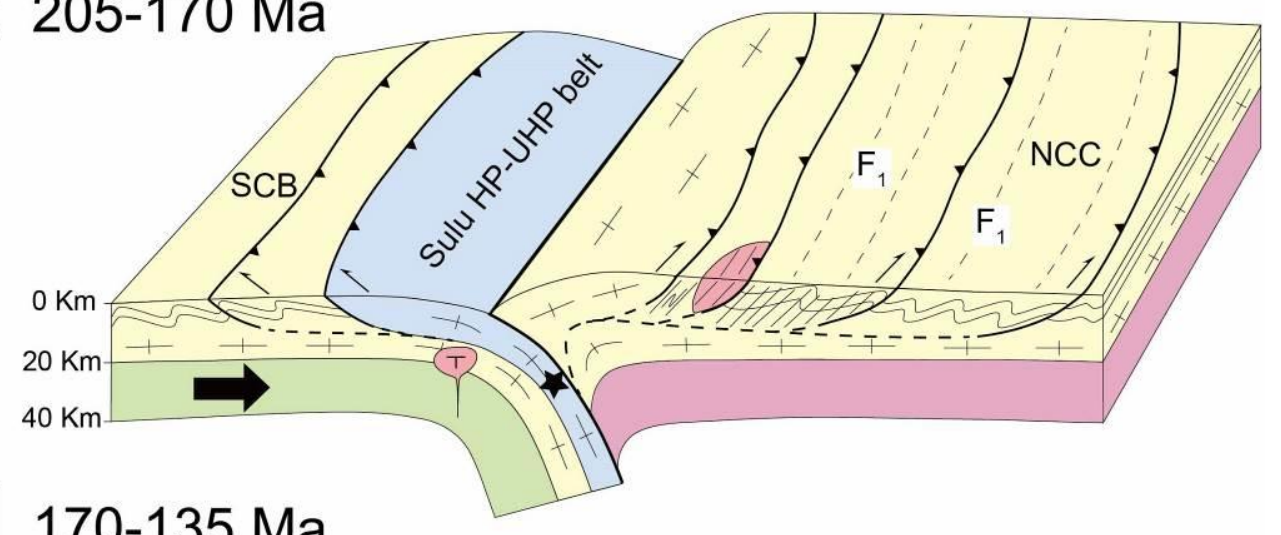

170-135 Ma

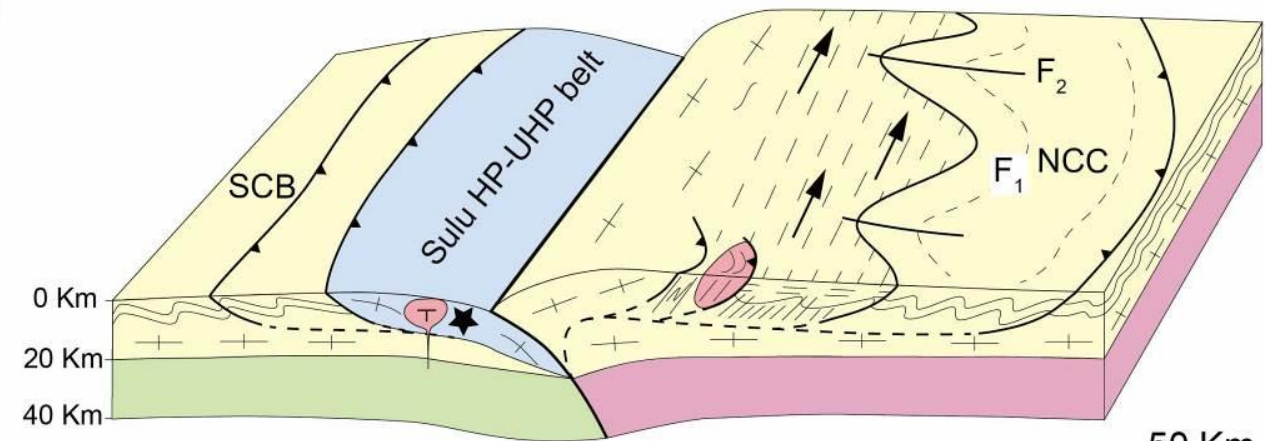

$50 \mathrm{Km}$

$\longrightarrow$ Thrust faults $\longrightarrow$ Normal faults IIII $\mathrm{S}_{1} \equiv \equiv \mathrm{S}_{2} \rightarrow \mathrm{L}_{2}$

$+\rightarrow$ Basement $\backsim$ Folded sedimentary rocks $\nsucc$ Eclogites

\begin{tabular}{|l|l|l|l}
\hline$T$ & $T$ Late Triassic complex $\quad \square$ & Middle-Lower crust of NCC and SCB
\end{tabular} 
Fig. 12. Tectonic evolution of the Lushun-Dalian area, South Liaodong Peninsula. a, NE-verging folds and NE-directed thrusts developed in the southern margin of NCC during the NCC-SCB convergence at 254-220 Ma; b, Alkaline magmatic complexes intruding into the middle crust during the extensional exhumation of the UHP metamorphic rocks at 220-205 Ma; c, Thrusting and ductile shearing of the Yinjiacun complex in the South Liaodong Peninsula during the post-convergence NE-SW compression at 205-170 Ma; d, Reworking of the NE-SW compressional structures. A fold interference pattern developed during the NW-SE compression at 170-135 Ma. 
Fig. 1. Simplified tectonic framework of the NCC and the location of the South Liaodong Peninsula (modified from Cho et al., 2007; Wang et al., 2011b; Clinkscales and Kapp, 2019). NCC: North China Craton; SCB: South China Block.

Fig. 2. a Simplified geological map of the South Liaodong Peninsula. b The sedimentary sequence of the South Liaodong Peninsula (modified from Yang et al., 2011; LBGMR, 1989) showing the structural layers of the Lushun-Dalian area.

Fig. 3. a Structural map of the Lushun-Dalian area. b, $\mathbf{c}$ and d Cross sections through the Lushun-Dalian area (locations in Fig. 3a) drawn parallel to the direction of the main mineral and stretching lineation. e and f Equiareal stereograms (Schmidt net, lower hemisphere) of the structural elements.

in sections b c d put the orientation SW-NE; NW-SE, WNW-ESE 
Fig. 4. Field photographs of structures associated with the $D_{1}$ deformation. a Syenite intrusion and country rocks concurrently foliated ( $\left.38^{\circ} 45^{\prime} 56.63^{\prime \prime}, 121^{\circ} 8^{\prime} 43.911^{\prime \prime}\right)$. b Gabbro intrusion and the country rocks concurrently deformed (38 $\left.{ }^{\circ} 44^{\prime} 16.88^{\prime \prime}, 121^{\circ} 9^{\prime} 7.52^{\prime \prime}\right)$. c Stretching $\mathrm{L}_{1}$ lineation exhibited on the $\mathrm{S}_{1}$ foliations in slate

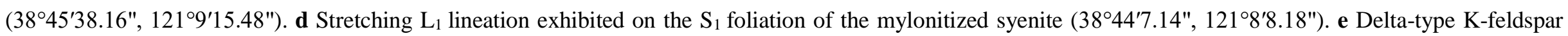
porphyroclast in the mylonitized syenite indicating a top-to-the-NE shear sense (38 $\left.45^{\prime} 19.5^{\prime \prime}, 121^{\circ} 7^{\prime} 40.09^{\prime \prime}\right)$. f Penetrative SW-dipping $\mathrm{S}_{1}$ and small intrafolial folds in the slate of the country rocks of the Yinjiacun complex (38 $\left.46^{\prime} 3^{\prime \prime}, 121^{\circ} 8^{\prime} 8.77^{\prime \prime}\right)$. g Subvertical $\mathrm{S}_{1}$ in the siltstone of Diaoyutai Formation, east of Lushun city

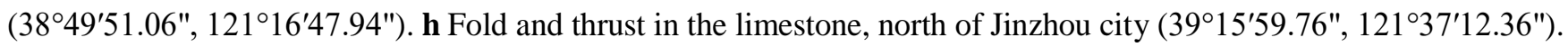

Fig. 5. Field photographs and microphotograph of structures associated with the $\mathrm{D}_{2}$ deformation. a Intrafolial $\mathrm{F}_{2}$ fold preserved in slate of the Qiaotou formation (38 $\left.55^{\prime} 16.23^{\prime \prime}, 121^{\circ} 9^{\prime} 9.49^{\prime \prime}\right)$. b NW-SE trending mineral stretching $\mathrm{L}_{2}$ lineation developed in the $\mathrm{S}_{2}$ foliation of the Diaoyutai formation (38 $\left.48^{\prime} 24.97^{\prime \prime}, 121^{\circ} 17^{\prime} 27.72^{\prime \prime}\right)$. c Sigmoidal quartz boudins in the Qiaotou formation indicating a top-to-the-NW shearing (38 $\left.47^{\prime} 29.41^{\prime \prime}, 121^{\circ} 16^{\prime} 40.75^{\prime \prime}\right)$. d Sigma-type quartz porphyroclast in the slate of the Diaoyutai formation indicating a top-to-the-NW shearing (38 $\left.48^{\prime} 43.63 ", 121^{\circ} 17^{\prime} 24.82^{\prime \prime}\right)$.

Fig. 6. a Detailed structural map of the Yinjiacun magmatic complex. b Equiareal stereogram (Schmidt net, lower hemisphere) of the $\mathrm{S}_{1}$ foliation and $\mathrm{L}_{1}$ lineation in the Yinjiacun complex and its country rocks. $\mathbf{c}$ and $\mathbf{d}$ NE-SW and NW-SE cross-sections of the Yinjiacun complex and its country rocks, respectively.

in sections $\mathrm{c} d$ put the orientation SW-NE; NW-SE,

section $\mathrm{c}$ not in agreement with the map to the NE, at leat indicate the limit of the map by a vertical line 

Fig. 7. a Cathodoluminescence images of representative zircons from the gabbro and syenite samples. Red ellipses indicate the analytical spots with measured ages. b and $\mathbf{c}$ SIMS U-Pb concordia diagram of the analyzed zircons, sample locations are shown in Fig. 6a.

Fig. 8. Schematic block diagram showing the $\mathrm{D}_{1}$ and $\mathrm{D}_{2}$ deformations of the Lushun-Dalian area, South Liaodong Peninsula. 
Fig. 9. Tectonic evolution of the Lushun-Dalian area, South Liaodong Peninsula. a NE-verging folds and NE-directed thrusts developed in the southern margin of NCC during the NCC-SCB convergence at 254-220 Ma. b Alkaline magmatic complexes intruding into the middle crust during the extensional exhumation of the UHP metamorphic rocks at 220-211 Ma. $\mathbf{c}$ Thrusting and ductile shearing of the Yinjiacun complex in the South Liaodong Peninsula during the post-convergence NE-SW compression at 211-190 Ma. d Reworking of the NE-SW compressional structures. A fold interference pattern developed during the NW-SE compression at 170-135 Ma.

Use another light color for the SCB crust, in order to clearly separate the NCB and SCB 